This is a pre-copyedited version of an article accepted for publication in Criticism 62(1) Winter 2020 following peer review. The definitive publisher-authenticated version is available from Wayne State University Press. 


\title{
Anne Bradstreet's Family Plots: \\ Puritanism, Humanism, Posthumanism
}

Patricia Phillippy

\author{
Out of maize \& air \\ your body's made, and moves. \\ - John Berryman ${ }^{1}$ \\ I can no more live without correction then \\ without food... [I] haue rather been \\ preserved with sugar then brine. \\ -Anne Bradstreet ${ }^{2}$
}

\section{Error of late sprunge upp}

Writing his will in April 1652, Thomas Dudley, sometime Governor of the Massachusetts Bay Colony and father of Anne Bradstreet, witnessed his hatred of "euery falce way in religion":

not onely the Old Idolitry and superstition of Popery, which is wearing away, but much more (as being much worse) the more heresies blasphemies \& error of late sprunge upp in our natiue country of England \& secretly recei[v]ed \& fostered more than I wish they were. ${ }^{3}$

\footnotetext{
${ }^{1}$ John Berryman, "Homage to Mistress Bradstreet," in Collected Poems, 1937-1971 (Farrar, Straus \& Giroux, 1989), 133.

2 Anne Bradstreet, “Andover Manuscript," Harvard AM MS 1007.1, 56-7. All subsequent citations are to this manuscript, indicated parenthetically as AM. The manuscript has been digitized by Harvard. It was first printed by John Harvard Ellis, The Works of Anne Bradstreet in Prose and Verse (Charlestown: Abram Cutter, 1867). A modernized version appears in Jeannine Hensley, ed., The Works of Anne Bradstreet (Cambridge: Harvard University Press, 1967), 261-322. AM is available in a facsimile edition in Anne Bradstreet, The Tenth Muse (1650), and from the Manuscripts, 'Meditations Divine and Moral' and Occasional Pieces, Introduction by Josephine K. Piercy (Gainesville, FL: Scholars' Facsimiles and Reprints, 1965), but the quality of the copy is very poor.

${ }^{3}$ New England Historical and Genealogical Register, Suffolk County Wills: Abstracts (Baltimore: Genealogical Publishing Co., 1984), 45. Dudley died on July 31, 1653 and,
} 
Dudley's Puritanical complaint reminds us of the polemics and prejudices tying New England to Old, and of the figures commonly used to express them. Dudley imagines the fertile ground of belief, from which heresies spring like poisonous plants and spread surreptitiously, a diabolical underbrush snagging the heels of Christian pilgrims. Similar spatial metaphors, replete with scriptural inflections, attended the founding of the colony. When minister John Winthrop landed for the first time in Salem with Dudley and his family, fellow passengers on the Arbella in 1630, he found "so pleasant a sweet air as did much refresh us, and...a smell off the shore like the smell of a garden." ${ }^{4}$ Responsive to the correlation of body and place, Anne Bradstreet later recalled, "my heart rose" at her first sight of this "new world and new manners," a symptom of her grief rather than joy. She suggests a period of gradual acceptance, a coming to terms whose details are unspoken: "But after I was conuinced it was $y^{\mathrm{e}}$ way of God, I submitted to it \& ioined to $\mathrm{y}^{\mathrm{e}} \mathrm{ch}^{\mathrm{urc}} \mathrm{h}$ at Boston" (AM 44). Three years before her father's death, Bradstreet's collection of poetry, published by her brother-in-law in London, similarly rooted body to earth, imagining the New World as a material field engendering The Tenth Muse, Lately sprung up in America. ${ }^{5}$

Bradstreet's encounter with the new world encapsulates the central concern of this article. I wish to explore the interface between textuality and materiality — of bodies, things, and places - in her writings; an intersection where Bradstreet revises the spiritual metaphors of the male coterie within which she produced and published her poems, turning them toward

according to Rev. Samuel Danforth, "was buryed [at Roxbury] $y^{\mathrm{e}} 6^{\text {th }}$ day following." See New England Historical and Genealogical Register 34 (1880), 83.

${ }^{4}$ John Winthrop, History of New England from 1630 to 1649, ed. James Savage (Boston: Little, Brown \& Co., 1853), 1:23.

${ }^{5}$ Anne Bradstreet, The Tenth Muse, Lately sprung up in America (London: Stephen Botwell, 1650), A $1^{\mathrm{r}}$. Subsequent citations are to this edition and appear parenthetically as $T M$. Patricia Pender, Early Modern Women's Writing and the Rhetoric of Modesty (London: Palgrave, 2012), 149-66, argues persuasively that Bradstreet's manuscripts circulated in New England prior to their publication in London and that the poems printed in $T M$ show signs of having been selected (by Bradstreet, Woodbridge, or both) to include secular, political themes rather than the religious writings most often associated with women. 
living engagements with place. Certainly, the religious, political and humanist values of this coterie - consisting of Dudley, Anne's husband Simon Bradstreet, brother-in-law John Woodbridge, and clergymen associated with the family—resonate throughout The Tenth Muse. ${ }^{6}$ Yet, I argue, Bradstreet's sustained involvement with the local, immediate, material world grafts Puritanism's spiritual and spatial allegories to the physical actualities of place, with results that trouble and decenter their univocal force. In doing so, her interventions present themselves to twenty-first century readers as distinctly posthuman. ${ }^{7}$

The "physical actualities" informing Bradstreet's works are, of course, difficultindeed, impossible — to recover: the Salem shoreline in 1630 was no more Winthrop's paradise than Bradstreet's wasteland. Four decades ago, Carolyn Merchant excavated the material foundations of these ecological images: "The Puritan wilderness," she notes, "was a cultural metaphor at odds with both the parklike forests they beheld on arrival and the meadowed landscape they created soon afterward." Mobilized within "an environmental

\footnotetext{
${ }^{6}$ See Gillian Wright, Producing Women's Writing, 1660-1730 (Cambridge University Press, 2013), 57-96; Pender, Early Modern Women's Writing; Katharine Gillespie, Women Writing the English Republic, 1660-1730 (Cambridge University Press, 2017), 200-202; and Robert Boschman, In The Way of Nature: Ecology and Westward Expansion in the Poetry of Anne Bradstreet, Elizabeth Bishop and Amy Clampitt (Jefferson, NC: McFarland, 2009), 45 and 121-41.

${ }^{7}$ See Cary Wolfe, What is Posthumanism? (Minneapolis: University of Minnesota Press, 2010); Rosi Braidotti, The Posthuman (Cambridge: Polity Press, 2013); and Donna J. Haraway, "A Cyborg Manifesto" (1985), reprinted in Simians, Cyborgs, and Women: The Reinvention of Nature (New York: Routledge, 1991), 149-82. Posthumanism has begun to influence early modern studies, but has made virtually no inroads into scholarship on women's writing in the period. Recent studies of early modern posthumanism include Karen Raber, Shakespeare and Posthumanist Theory (London: Bloomsbury, 2018); Joseph Campana and Scott Maisano, eds. Renaissance Posthumanism (New York: Fordham University Press, 2016); Rebecca Laroche and Jennifer Munroe, Shakespeare and Ecofeminist Theory (London: Bloomsbury, 2008); and Valerie Traub, ed., The Oxford Handbook of Shakespeare and Embodiment. Gender, Sexuality, and Race (Oxford University Press, 2016). Notable titles in early modern animal studies are Laurie Shannon, The Accommodated Animal: Cosmopolity in Shakespearean Locales (University of Chicago, 2013); Erica Fudge, "The Animal Face of Early Modern England," Theory, Culture \& Society 33.7/8 (2013), 177-98; and Karen Raber, Animal Bodies, Renaissance Culture (Philadelphia: University of Pennsylvania, 2013).
} 
ethics," these images facilitated "an ecological revolution" in New England: by roughly 1675, the native ecosystem was utterly displaced by the European. ${ }^{8}$ Sprung up amid this revolution, The Tenth Muse propagates the metaphors attending these technologies, while registering none of the seismic material changes they wrought. In this sense, Bradstreet's book is more English than American: the Muse "(From th' Orient first sprung) now from the West" (TM, $\mathrm{A} 7^{\mathrm{v}}$ ) attests to this colonial cultivation.

Yet if Bradstreet does not write "against the patriarchal grain,"9 a strain of resistance — resonant with semiotic and spiritual doubt, self-doubt, critical observation and challenge; a duet of orthodoxy and originality—sounds throughout her writings.

Reintroducing materiality into a reading of Bradstreet's works, I contend, brings this challenge to the fore. The discussion that follows adopts a new materialist strand of posthumanism, which understands the human as interlaced with the agency of the material world, to describe Anne Bradstreet's challenge to Puritanism's notional divisions of the world into more or and less valid, and valued, opposites. ${ }^{10}$ In her hands, I argue, the borders

\footnotetext{
${ }^{8}$ Carolyn Merchant, Ecological Revolutions: Nature, Gender and Science in New England (Chapel Hill: University of North Carolina Press, 1989), 100-102 and 70. See also Carolyn Merchant, The Death of Nature: Women, Ecology, and the Scientific Revolution (San Francisco and London: Harper \& Row, 1979), a foundational work in ecofeminism. ${ }^{9}$ Boschman, In the Way, 46.

${ }^{10}$ See Karen Barad, Meeting the Universe Halfway: Quantum Physics and the Entanglement of Matter and Meaning (Durham, NC: Duke University Press, 2007); Elisabeth Grosz, Volatile Bodies: Toward a Corporeal Feminism (Bloomington: Indiana University Press, 1994); Stacy Alaimo, Bodily Natures: Science, Environment, and the Material Self (Bloomington: Indiana University Press, 2010); and Stacy Alaimo and Susan Hekman, eds., Material Feminisms (Bloomington: Indiana University Press, 2007). On the position of new materialism within posthumanist theory, see Raber, Shakespeare, 14-17; William E. Connolly, “The 'New Materialism' and the Fragility of Things," Millennium: Journal of International Studies 41 (2013), 399-412; and William E. Connolly, The Fragility of Things: Self-Organizing Processes, Neoliberal Fantasies, and Democratic Activism (Durham, NC: Duke University Press, 2013). On the continuities between new materialist ideas and traditional cultural studies, see Raber, Shakespeare, 33-8 and 58-9; and Suzanne Letlow, "Turning the turn: New materialism, historical materialism and critical theory," Thesis Eleven, 140 (2017), 106-21. The distinguishing feature between 'old' materialism and new is the latter's posthumanist aim of decentering the normative binaries that define the humanist subject, thus revealing the embodied entanglement of the human and nonhuman.
} 
between nature and culture dissolve, enabling her to distill from the husks of Puritan and humanist commonplaces original reconfigurations of the multiple partnerships of the human and nonhuman.

As such, a central concern of this study is to consider how the alignment of woman with nature can fruitfully move beyond the essentialism by which scholarship on women's writing is sometimes beset. Early criticism in this field largely embraced an essentialist view of women and an identity politics that linked subjects - those of critical study and the critics who studied them - to each other. To address these troubles, scholars moved toward a view of gender as socially constructed and performative: women as well as their texts are wholly discursive entities. Writing is a "situated knowledge," as Donna Haraway put it, practiced in circles and coteries where cultural threads weave through texts circulating there. ${ }^{11}$

While this social constructivist turn has been rich and productive, its practitioners remain loath to engage corporeality, perhaps fearing a relapse into the essentialism of woman's 'nature.' Yet despite this reliance on discursive subjectivities, a latent identity politics persists, not least in our choice of subject. When Merchant couples the "antianimality" that licensed colonial "subordination of wild nature to human culture" with the claim that "Puritan fathers...legitimated the subjugation of the wilderness and the subjugation of women," she posits an essentialist equation of women, animals, and nature that sanctions not merely human, but specifically masculine, exceptionalism. ${ }^{12}$ This alignment of women and wilderness takes no account of — nor has it prompted engagement with-Puritan women's writings that may interrogate and challenge the nature/culture binary on which patriarchy depends. Policing the borders between nature and culture, scholarship on

${ }^{11}$ Donna J. Haraway, "Situated Knowledges: The Science Question in Feminism and the Privilege of Partial Perspective," Feminist Studies, 14.3 (Autumn 1988), 575-99.

${ }^{12}$ Merchant, Ecological Revolutions, 100. 
women's writing produces vivid portraits of women's engagement in literate sociability, quite set apart from the material worlds and bodies in which they lived.

A new materialist perspective on this critical impasse can mark out a new path beyond essentialism. Matter (the human body included), Karen Barad writes, "is not a static entity. It is not little bits of nature, or a blank slate, surface, or site passively awaiting signification."13 The replacement of natural, essential bodies by subjects who are discursively inscribed overlooks both the agency of matter and the embodiment of discourse, merely replacing biological essentialism with a linguistic determinism that imposes a destiny of its own. Insisting on the agency and entanglement of matter in all of its forms, new materialism views subjects as at once materially and discursively co-constituted: "materiality is discursive," as Barad puts it, "just as discursive practices are always already material." ${ }^{4}$ The understanding that there is no taking the body out of discourse, and vice versa, has instructively redirected Merchant's later scholarship, which proposes “for the twenty-first century...a partnership ethic [which] holds that the greatest good for the human and nonhuman communities is in

\footnotetext{
${ }^{13}$ Barad, Meeting the Universe Halfway, 150-1.

${ }^{14}$ Barad, Meeting the Universe Halfway, 151.
} 
their mutual, living interdependence." 15 This ethic invites us to reconsider nature, "no longer symbolized as virgin, mother, or witch but instead as an active partner with humanity." 16

Taking up this invitation here, I read Bradstreet's writings with an eye to the interfaces joining bodies and places in mutual, emergent partnerships. My goal is to reconstitute an archive that takes account of matter as existing beyond text. Focusing primarily on Bradstreet's “Andover Manuscript," I adopt a new materialist view of corporeality as simultaneously material and discursive to explore Bradstreet's sense of human and nonhuman bodies and places as continuous and co-produced. This idea, in turn, reimagines the individual subject no longer as occupying a bounded, self-enclosed body, insulated from a world beyond. Rather than residing in a stable corporeal rind, individuals, like environments, are permeable and intertwined. For Bradstreet, this entanglement complicates the rigid dichotomies of orthodox belief, opening a space for mobile creativities rooted in the body but free from the brand of essentialism.

\footnotetext{
${ }^{15}$ Carolyn Merchant, Ecological Revolutions: Nature, Gender and Science in New England, 2nd edition (New York: Routledge, 2010), 277. Revised editions of Merchant's works originally published in the 1980s incongruously restate their essentialist claims while unsettling them in updated prefaces and epilogues. This partnership ethic was first outlined in Carolyn Merchant, Reinventing Eden: The Fate of Nature in Western Culture (New York: Routledge, 2003), 223-45, and reiterated in the second edition of Carolyn Merchant, Radical Ecology: The Search for a Livable World (1992; New York: Routledge, 2005), 82-90. See Victoria Dawson, "Is Ecofeminism Ecofeminist?" in Ecological Feminism, ed. Karen Warren (London: Routledge, 1994), 8, on Second Wave assertions of "a link between the domination of women and the domination of nature;" and see Rebecca Laroche and Jennifer Munroe, eds., Ecofeminist Approaches to Early Modernity (London: Palgrave, 2011); and Stacy Alaimo, Undomesticated Ground: Recasting Nature as Feminist Space (Ithaca: Cornell University Press, 2000) on current ecofeminism's destabilization of essentialism.

${ }^{16}$ Carolyn Merchant, "Scientific Revolutions and the Death of Nature," Isis, 97.3 (September 2006), 515.
} 


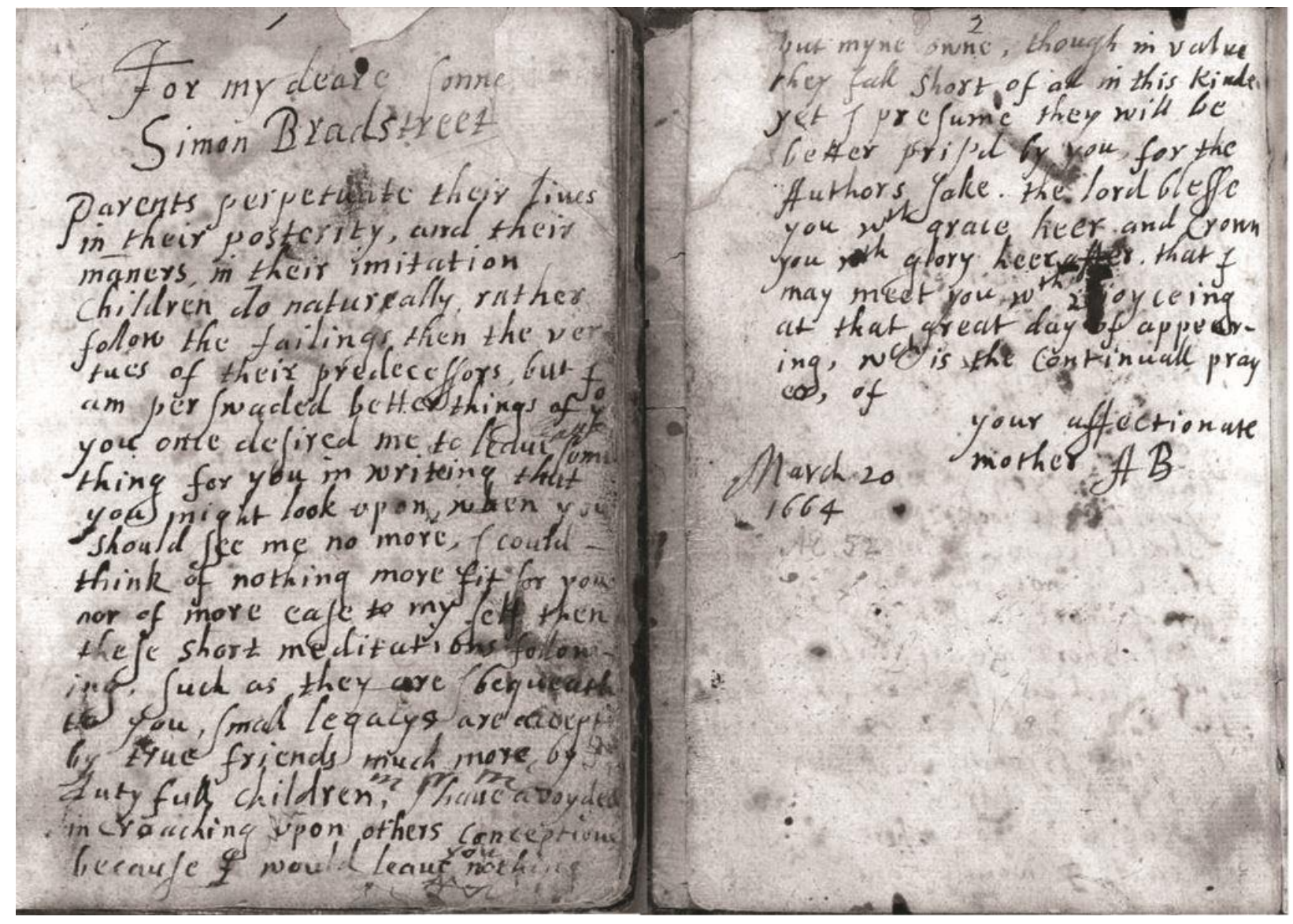

Figure 1. Anne Bradstreet, "Meditations Diuine and Morall," (holograph). Harvard AM MS 1007.1, pp. 1-2. Reproduced by permission of the Trustees of the Stevens Memorial Library.

I follow the passage of my "material Muse" through New England, charting a course from the settlement, to the hearth, to the hearse ${ }^{17}$ Part 2 of this article finds in the posthumously published "Contemplations" Bradstreet's acknowledgment and use of the permeability of the human and nonhuman in natural and domestic spaces to create new, autonomous meanings in spiritual and secular registers. In Part 3, I locate this materialdiscursive coproduction of body and place in the "Andover Manuscript," a composite volume containing Bradstreet's holograph collection of seventy-seven "Meditations Diuine and morall," and a "Book by Any yet unread," composed in prose and poetry, copied by her son

${ }^{17}$ I adapt the phrase from Wright, Producing Women's Writing, 93, where it is applied within a history of the book approach to Bradstreet's writings. 
Simon after his mother's death in 1672 (see figures 1 and 2). In these works, I argue, Bradstreet's emphatic involvement in the places and technologies of domesticity allows her an interpretive autonomy that enlivens and embodies commonplace religious emblems within a story of resistance, doubt, and self-doubt. Finally, Part 4 returns to "Contemplations" to join the artifactual remnants of Bradstreet's career with their textual traces. Bradstreet's record of the bodily processes of death, burial, and commemoration offers stark emblems of the entanglements of human and (suddenly, mournfully) nonhuman in terms that resonate with the physicality traversing her corpus. Across these sites, Bradstreet's tentative gestures toward transcendence, embodied in monumental forms and texts, display instead a stubborn strain of embodiment that joins subjects across the porous threshold between life and death. Eloquently opening a space for reading premodern periods through a posthumanist lens, Cary Wolfe posits a posthumanism that "comes both before and after humanism." We are increasingly aware that we now live "after humanism," when our imbrication in nonhuman networks (technical, biomedical, and informatic, among others) destabilizes traditional views of "the human." But posthumanism precedes humanism, Wolfe explains: 


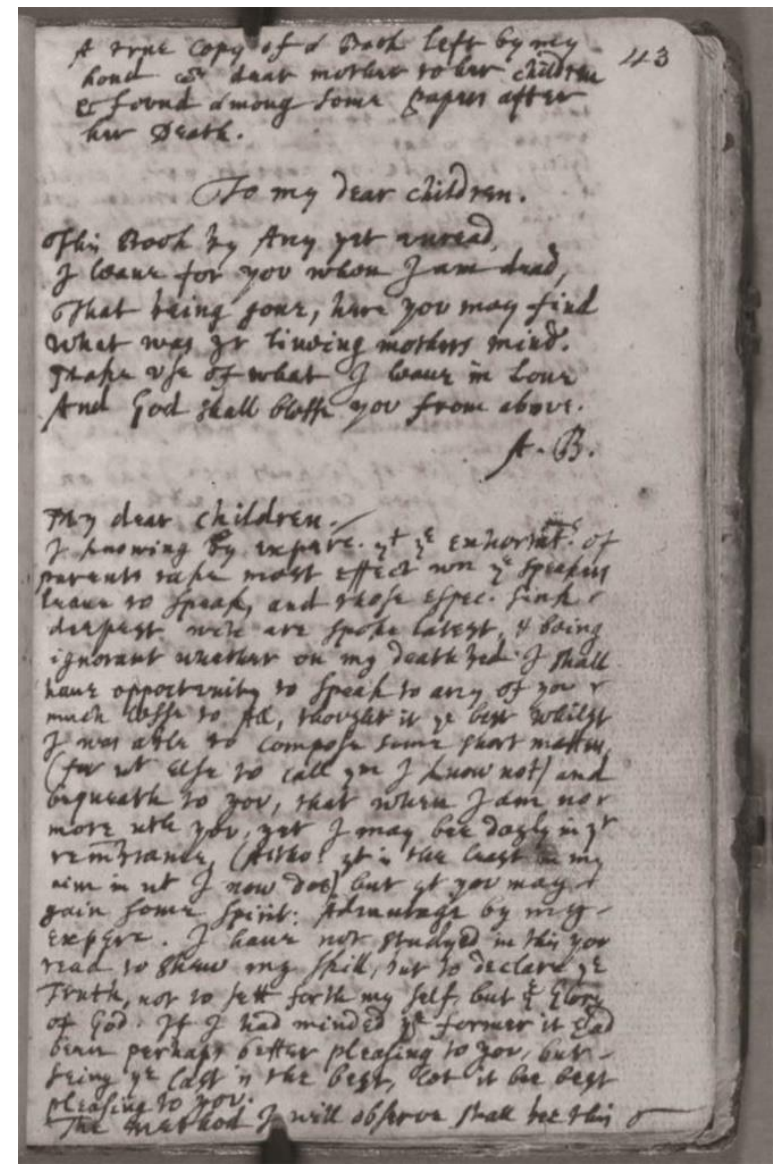

Figure 2. Anne Bradstreet, “A Book by Any yet unread,” copied by Simon Bradstreet.

Harvard AM MS 1007.1, p. 43. Reproduced by permission of the Trustees of the Stevens

\section{Memorial Library.}

in the sense that it names the embodiment and embeddedness of the human being in not just its biological but also its technological world, the prosthetic coevolution of the human animal with the technicity of tools and external archival mechanisms (such as language and culture)...all of which comes before that historically specific thing called 'the human.' 18

Wolfe's insistence that posthumanism neither discards nor transcends the human or humanism — that is, his insistence on embodiment — accords with the new materialist view

${ }^{18}$ Wolfe, What is Posthumanism?, xv. 
that 'environment' is not external to the subject, but is the condition and material of the body itself. ${ }^{19}$ Attuned to the complex systems connecting the body and the world, the posthumanist poet Bradstreet recommits the transcendental poetics of humanism and Puritanism to matter. $^{20}$

\section{2. a place unstable}

In the entanglement of body and place, both are actors and authors: the world is not inert matter, raw material, or a backdrop for human activities, but a partner in creation and existence. I begin with a work that stages Bradstreet's awareness of this partnership, a poem she prepared for a second edition of The Tenth Muse, published posthumously in Several Poems. ${ }^{21}$ "Contemplations" finds the speaker "Silent alone, where none or saw, or heard, / In pathless paths," wondering as she goes at the beauty surrounding her:

Some time now past in the Autumnal Tide,

When Phoebus wanted but one hour to bed,

The trees all richly clad, yet void of pride,

Where gilded o're by his rich golden head.

Their leaves \& fruits seem'd painted, but was true

Of green, of red, of yellow, mixed hew,

\footnotetext{
${ }^{19}$ See Wolfe, What is Posthumanism?, xvi-xvii; For the new materialist insistence on embeddedness and embodiment, see, for example, Grosz, Volatile Bodies; and Alaimo, Bodily Natures.

${ }^{20}$ See N. Katherine Hayles, How we Became Posthuman: Virtual Bodies in Cybernetics, Literature and Informatics (University of Chicago Press, 1999) for the view that posthumanism involves transcendence of embodiment. I agree with Wolfe's description of this position as a "transhumanism" that intensifies humanism rather than decentering it: see What is Posthumanism?, xvi.

${ }^{21}$ Anne Bradstreet, Several Poems (Boston: John Foster, 1678), 221-9. Subsequent citations are to this edition and appear parenthetically as $S P$. None of the poems published in Several Poems appear in AM, and the AM poems, along with the prose works, remained unpublished until Ellis's annotated edition.
} 
Rapt were my senses at this delectable view. ${ }^{22}$

Although the poem seems at first to equate women's and nature's essences, Bradstreet pursues a more cultivated, transcultural image of the female speaker and the space she inhabits. The familiar rivalry between art and nature signals Bradstreet's poetic virtuosity, here demonstrated in her artful appropriation of rime royale, formally advancing this 'nature poet' as heir to a transcultural literary legacy. ${ }^{23}$ Phoebus, the classical patron of music, poetry, and prophecy guides and illuminates the speaker's contemplation and the verses she performs. The god's legendary birth on the floating island of Delos, further, underwrites the speaker's meandering and the variable landscape — captured at the turning of both day and season-where she brings forth her poem. Golding's translation of Ovid's Metamorphoses associates the maternal body with the land, but casts both as wildly unstable and "fleet[ing]": "Delos pitying hir, sayde Thou doste fleete on land, / And I on Sea, and thereupon did lende hir out of hand / A place unstable." ${ }^{24}$ Rather than imagining both woman and land as lying prone before man's subjugating rule, the myth decenters this essentialism. Set it in motion as a subtext in "Contemplations," the trace of this kinetic couple joins human and nonhuman, female and male, land and sea. ${ }^{25}$

Situating this myth of mobility in the New World, Bradstreet registers the foreign, colonial presence that permeates her landscape. Indeed, as Michael Ziser has shown,

\footnotetext{
${ }^{22}$ Bradstreet, stanzas 8 and 1 . All citations are to $S P$ by stanza numbers ( $S P$ has no line numbers). The printing is erroneously numbered in two places (225-6 and 227-8), involving stanzas 19, 20, 27 and 28. These errors have been silently amended.

${ }^{23}$ Lee Oser, "Almost a Golden World: Sidney, Spenser, and the Puritan Conflict in Bradstreet's 'Contemplations,"” Renascence 52 (Spring 2000), 187-202, notes Fletcher and Quarles as immediate sources for Bradstreet's stanza.

${ }^{24}$ Ovid, Metamorphoses, trans. Arthur Golding (London: 1567), 6:242-4. I am indebted to Bonnie Grahame-Betts for pointing out this association with Delos.

${ }^{25}$ Although Bradstreet does not explicitly mention Phoebus's birth, the story is implicit in the description of the Sun's "swift Annual and diurnal Course" (6) and the gestational imagery associated with the sun's effect on the "darksome womb of fruitful nature (5). The choice of Phoebus rather than Helios as the sun god enables Bradstreet to mobilize this myth.
} 
"Contemplations" commences not in the American wilderness, but in a clearing on the edge of a settlement, "where the native hardwoods—spectacular in autumn—had a tendency to spring up after the clearing of white pine and other conifers." ${ }^{26}$ Bradstreet's imagery, more precisely, describes not native hardwoods but an English import, the botanical equivalent of rime royale: an apple tree, as Ziser argues, "the only green, red, and yellow fruit at that season at that point in Massachusetts." Far from inhabiting a virginal landscape, the speaker is discovered in "a spectacular clearing into which both European and American natures have rushed and intermingled."27 Apple orchards, transplanted in America by English settlers, were commonly situated at the borders of towns and settlements. On her death in 1713 , Simon Bradstreet's second wife, also an Ann Bradstreet, bequeathed to female kinswomen her "Orchard, Garden \& Appertenances, Situate in Salem" (see figure 3). ${ }^{28}$ When Anne Bradstreet joined the church at Boston in 1630, William Blackstone's apple orchard, planted at the corner of Beacon and Spruce Streets, bore fruit. ${ }^{29}$

Bradstreet's speaker occupies this clearing for the first twenty stanzas of "Contemplations" before she ventures further from this man-made nature to "A lonely place...by a goodly Rivers side" (21), where the poem changes direction topographically and discursively. ${ }^{30}$ In this initial movement of the poem, though, Bradstreet mobilizes the commonplaces of the Book of Nature to interrogate the entanglement of human and nonhuman, staking out the terms of her inquiry in material and discursive fields. As the affinity between

\footnotetext{
${ }^{26}$ Michael Ziser, Environmental Practice and Early American Literature (Cambridge University Press, 2013), 98.

${ }^{27}$ Ziser, Environmental Practice, 98.

${ }^{28}$ Anon., "The Will of Ann Bradstreet, the Second Wife of Governor Simon Bradstreet," in Historical Collections of the Essex Institute, Volume IV (Salem: G. M. Whipple and A. A. Smith, 1862), 186-90 at 186.

${ }^{29}$ Ziser, Environmental Practice, 90.

${ }^{30}$ See Michael G. Ditmore, "Bliss Lost, Wisdom Gained: Contemplating Emblems and Enigmas in Anne Bradstreet's 'Contemplations," Early American Literature 42 (2007), 3172 , for a similar view of the poem's structure.
} 
Delos and Latona rests on their like material conditions (they both "fleete") and their dialogic engagement (Delos speaks in reply to Latona's complaint), Bradstreet explores the polyglossia

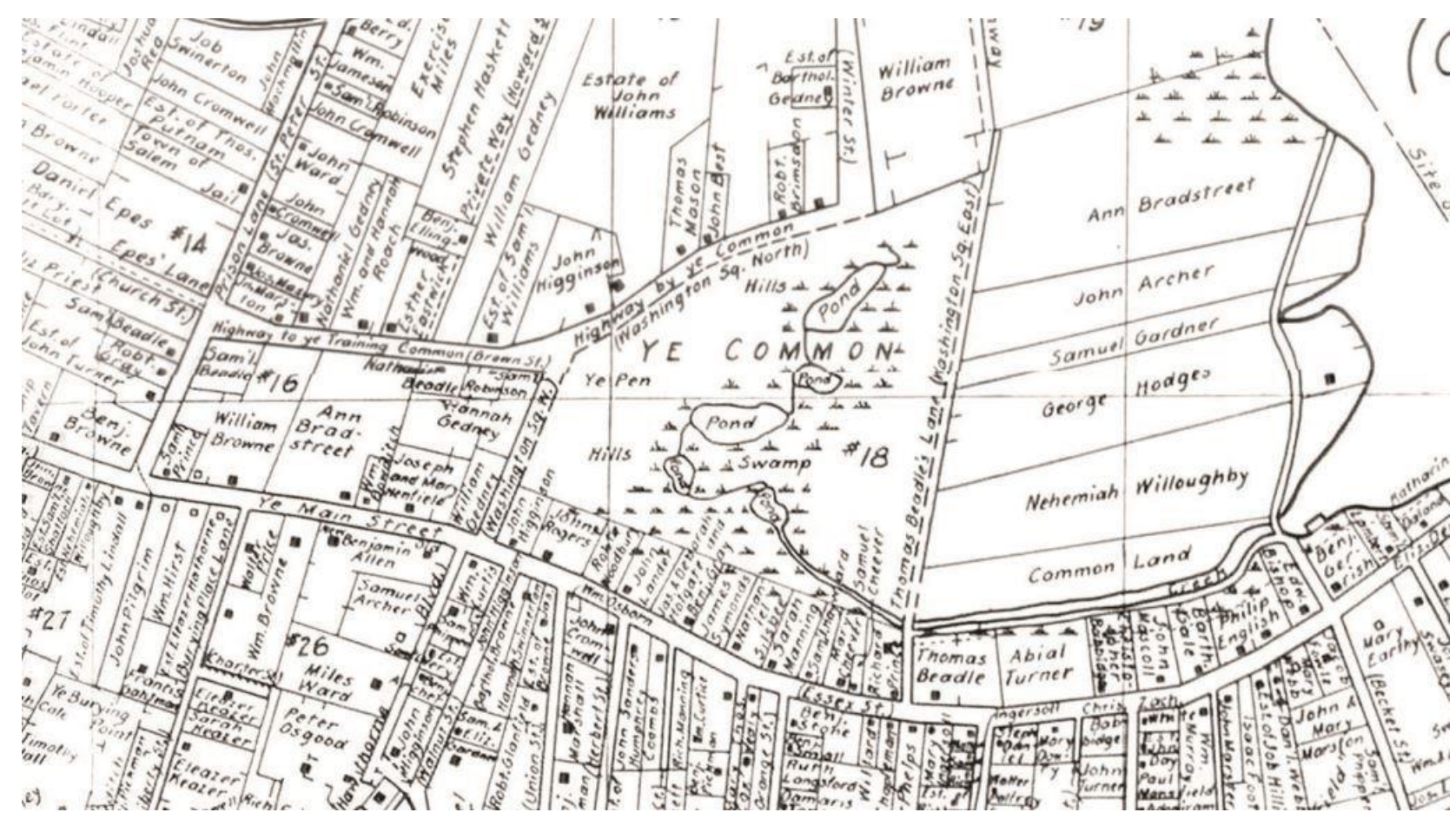

Figure 3. Sidney Perley and William Freeman, "Part of Salem in 1700" (detail). Salem Witch Trials Documentary Archive and Transcription Project, University of Virginia. Used by permission.

of creaturely companionship. In her animate landscape — where, it seems, "natural and human history are one and the same" - the trees, "clad, yet void of pride," display the best of human virtues, humility. "Silent alone," the speaker is neither: thus she addresses "a stately Oak" (3), and demands of the sun, "what glory's like to thee?" (4), before being rendered "as mute" when her poetic rivals, "the merry grashopper" and "the black clad Cricket" (9), become, as Milton put it, "speakable of mute." 32

Surpassed by nature's "little art” (9), the speaker moves from considering the glory of nature to the lot of humankind, returning to the story of the first family to determine whether

\footnotetext{
${ }^{31}$ David Glassberg, "Place, Memory and Climate Change," The Public Historian 36:3 (August 2014), 20-1.

${ }^{32}$ John Milton, Paradise Lost, ed. David Loewenstein (Cambridge University Press, 2004), 9:563.
} 
man is other than an animal among others. In its material and discursive settings, Bradstreet's apple tree, like her father's field of heresies, is an overdetermined sign. Thus it is fitting that "Contemplations" should turn away from the tree before the speaker's eyes to the perennial Edenic fruit: "glorious Adam," she recalls, "made Lord of all, / Fancyes the Apple, dangle on the Tree, / That turn'd his Sovereign to a naked thral" (11). Yet as she pivots to the biblical tale, she troubles the relationships between human and nonhuman in Genesis, and inverts the terms of the human exceptionalism implicit in Christian and humanist narratives. The sole remarkable act recounted in her compact Genesis is the violation of nature's purity, not by Adam's Fall but by Cain's fratricide: “The Virgin Earth, of blood her first draught drinks, / But since that time she often hath been cloy'd" (14). The notion that Cain pollutes an earth that is both post-lasparian and pure departs from the biblical source, where God tells Adam "cursed is the ground for thy sake" (Gen. 3:17). ${ }^{33}$ Accordingly, Bradstreet concludes that man, "By birth more noble then... creatures all" is "by nature and custome curs'd" (19, my italics). "Grief and care makes fall / That state obliterate he had at first," but this is a private rather than universal catastrophe: "Nor youth, nor strength, nor wisdom spring again...But in oblivion to the final day remain" (19). Nature and custom collude to propel the "fall" of each individual, one that is nothing more or less than life itself. Displaced from Adam to Cain, original sin occurs not in an unspoiled Eden but in a historicized landscape - a biblical clearing around the first family's settlement— constituted by nature and culture together. ${ }^{34}$ Cursed by nature and custom, Cain's “fate forlorn” (12) is everyman's.

In the distinction between man and nature, then, the human fares far worse than the nonhuman. Bradstreet's history of humankind ends on a note of utter devastation: in the brief, woeful passage that is human life, man "Joyes not in hope of an eternal morrow" nor dares to

\footnotetext{
${ }^{33}$ See also the Pauline gloss in Romans 8:19-23. All citations are to the King James Bible.

${ }^{34}$ Ditmore, "Bliss Lost," 38.
} 
"groan for that divine Translation" (29). If sons of Cain are undone by nature and culture, Bradstreet's speaker sees in "the emergent natureculture" of her pilgrimage continual rebirth and partnership; translations across kinds. ${ }^{35}$ Weighing the regeneration of nature against the "grief and care" of human existence, the speaker wonders, "Shall I then praise the heavens, the trees, the earth / Because their beauty and their strength last longer /...Because they're bigger, \& their bodyes stronger?" And the conventional apocalyptic response, "Nay, they shall darken, perish, fade and dye...But man was made for endless immortality" (20), appears particularly vacuous given man's deprivation of either "eternal morrow" or "divine Translation." ${ }^{36}$ For Bradstreet's inquisitive speaker, the endless tomorrows that nature enjoys seem to hold forth a more certain immortality. The earth is resilient and endlessly renewed: "I behold...the earth (though old) stil clad in green, / The stones and trees, insensible of time, / Nor age, nor wrinkle on their front are seen" (18). "Man," by contrast, "grows old, lies down, remains where once he's laid" (18).

If "Contemplations" struggles with the contemptus mundi demanded by humanist and Puritan orthodoxies, it is because Bradstreet crafts her speaker as a creature among others; involved with, embedded in, and committed to the nonhuman world. Although plotted by the teleological drama of Christian time - the phenomenal experience of the season recalls the Fall of Eden and looks forward to the fall of nature at the Second Coming - the poem resides at the imprecise, multiple seams lacing the wondering, wandering speaker to the stubborn immediacy of the material world.

This comingling of human and nonhuman agencies is the subject of the poem's second movement, which immediately follows - and quietly leaves behind - the hollow promise of "endless immortality":

${ }^{35}$ Donna J. Haraway, The Companion Species Manifesto: Dogs, People and Significant Otherness (Chicago: Prickly Paradigm Press, 2003), 1.

${ }^{36}$ See Ditmore, "Bliss Lost," 43, for a similar reading. 
Under the cooling shadow of a stately Elm

Close sate I by a goodly Rivers side,

Where gliding streams the Rocks did overwhelm;

A lonely place, with pleasures dignifi'd.

I once that lov'd the shady woods so well,

Now thought the rivers did the trees excel,

And if the sun would ever shine, there would I dwell. (21)

The cool, moist climate embodies the Galenic model of female anatomy, allowing Bradstreet to intertwine the "porous humoral bodies" of the speaker and the landscape. ${ }^{37}$ As the speaker joins herself and her desires to the "stealing stream" rushing unobstructed to "the long'd for Ocean" (22), the kinetic coupling of woman and land in the mythic subtext of the poem's opening stanza rises again to the surface. In this transitional moment, the speaker returns to nature to embrace what Laurie Shannon has called an Edenic "species memory"- the recovery of original "arrangements across kinds" that join humans and nonhumans in an ecosystemic mutuality. ${ }^{38}$ In the movement from woods to water, from the man-made nature of the clearing to a sympathetic, feminine site, the speaker also moves from past to future, from male to female rule, and from orthodoxy to originality. ${ }^{39}$

The coupling of poet and river marks the culmination of a series of images in the poem of female creative potential, from "the darksome womb of fruitful nature" (5), to the "Virgin Earth" (14), to Eve's delivery of Cain (11). Rather than adopting an essentialist view

\footnotetext{
${ }^{37}$ Gail Kern Paster, The Body Humored: Emotions and the Shakespearean Stage (University of Chicago Press, 2010), 20. See also Gillespie, Women Writing, 194-241 on Bradstreet's humoralism; Raber, Shakespeare, 55-68, on the link between humoral theory and posthuman bodies; and Nancy Tuana, "Viscous Porosity: Witnessing Katrina," in Alaimo and Hekman, eds., Material Feminisms, 188-211, for an excellent new materialist treatment of corporeal porosity.

${ }^{38}$ Shannon, Accommodated Animal, 80.

${ }^{39}$ Ditmore, "Bliss Lost," 44.
} 
of the connection between women and nature, however, Bradstreet's handling of these creative sites invites a reading of the female body as emergent in the intertwining of matter and discourse. Here, the "happy Flood" joins "a hundred brooks" (24) in her journey, and nurtures her felicitous fishes, childlike "wantons [who] frisk to tast the air" (25). The speaker's affinity with the river, their shared capacity for creativity and nurture, is set forth in images of maternity and domesticity: ${ }^{40}$

So hand in hand along with thee they glide,

To Thetis house, where all imbrace and greet:

Thou Emblem true, of what I count the best,

O could I lead my Rivolets to rest,

So may we press to that vast mansion, ever blest. (24)

Bradstreet's involvement with the technologies of female cultural production-poetic, procreative, and domestic - intervenes in the 'pure field' of natural creation, revising conventional figures of maternity to challenge essentialist conceptions of the natural female body. ${ }^{41}$ The poem and its speaker reside at the interfaces of gender, subjectivity and environment, where the material body is an "ecological body" - a being interlaced with natural and cultural environments and creatures, and brought into being by these entanglements. $^{42}$

It is no coincidence, then, that Philomel—an embodied translation across kindsappears at this moment to mark the poem's twilight with her transcultural song, reminding us

${ }^{40}$ See Rosamond Rosenmeier, Anne Bradstreet Revisted (Boston: Twayne, 1991), 150.

${ }^{41}$ Jean Marie Lutes, "Negotiating Theology and Gynaecology: Anne Bradstreet's Representations of the Female Body," Signs 22.2 (1997), 309-40, points to Bradstreet's manipulations of cultural figurations of maternity to challenge essentialist conceptions of the female body: Bradstreet's "Author to her Book," published with Several Poems, imagines the poem as offspring produced within "a matrix of creativities based on women's doublebirthing potential" (332).

${ }^{42}$ Linda Nash, Inescapable Ecologies: A History of Environment, Disease, and Knowledge (Berkeley: University of California Press, 2006), 127. 
that even here the "Virgin Earth" is co-resident with human agency. The nightingale's “melodious strain" prompts the speaker's desire to exchange human limitations for the freedom of the nonhuman: "[I] wisht me wings with her a while to take my flight" (27). Like the river, Philomel figures what the speaker "count[s] the best": the creative maternal power - the song of maternity — that unites and protects the family, leading them to the "beloved place" (22):

The dawning morn with songs thou dost prevent,

Sets hundred notes unto thy feathered crew,

So each one tunes his pretty instrument,

And warbling out the old begins anew,

And thus they pass their youth in summer season,

Then follow thee into that better Region.

Where winter's never felt by that sweet airy legion. (28)

Bradstreet crafts twin images of the household, its members united and led by creative matriarchs. Rather than constructing stable structures, though, her households are agile, fluid, and mobile. If the speaker prefers waters to woods, the qualities she seems most to admire are the unhindered motion of the rushing river, the unbridled flight of the nightingale, against the rootedness and inflexibility (spatial, temporal, and ideological) of the clearing. The new world of the poem's closing scene is an everchanging world of cooling shadows, rushing rivers, fluttering wings, while "Man grows old, lies down, remains where once he's laid." Informed by her Ovidian subtexts, Bradstreet's river and nightingale join Latona as "fleet[ing]," ungrounded women: female heads of households that are themselves fleeting, water-bound, and airborne. 
The qualities of maternal creativity developed in this tableau are predicted by Bradstreet's handling of the birth of Cain, which stages a homely scene of childbirth in the lap of nature:

Here sits our Grandame in retired place,

And in her lap, her bloody Cain new born.

The weeping Imp oft looks her in the face,

Bewails his unknown hap, and fate forlorn;

His Mother sighs, to think of Paradise,

And how she lost her bliss, to be more wise.

Believing him that was, and is, Father of lyes.

Stylistically, the passage is spatial, indicative, and ekphrastic_- "here" is Eve, "here Cain," "There Abel," (12-14) — as though the speaker is conducting the reader through the rooms of a house. Indeed, the intimate scene carries with it the remnants of the childbed, now placed at the threshold of domesticity. Eve's bloody lap, the newborn's interactions with his mother, her rueful sigh as she remembers Paradise lost—-her exile from her home, now embodied in the material reminders of painful labor and the "weeping Imp" that it brings forth — all paint a poignant picture of material-discursive maternity.

Bradstreet embeds in the image of Eve's natural childbed not the misogynistic metaphors the 'mother of man' typically elicits in the period, but the tactile, sensory, material remains of childbirth; the liminal moment when bodies utterly intertwined, borders porous and blurred, begin to take shape as two. This figuration relies on an understanding of the domestic, like the maternal, as kinetic, fleeting and porous - as an excess of materiality that continually overflows its borders. "At root," Laroche and Munroe write, "the household implies a set of binaries - inside/outside, culture/nature, human/nonhuman," yet these oppositions collapse in the relentless passage of bodies across the permeable borders of 
domestic space. Households are "sites of multiple thresholds crossed over and over againthe doorway, the mouth, the ear, the garden wall" (and, I would add, the childbed and the deathbed) "by multiple creatures and substances, human and non-human alike." 43 Although the household presents an illusion of containment - the orderly flow of a river within its banks; the stillness of a nesting bird - this illusion vanishes in the permeability of the domestic; in the peremptory arrivals of childbirth and the hapless departures of death. In Eve's natural bower, the site of a birth that is also a death, the illusion of containmentincluding women's illusory corporeal and domestic containment — dissolves in the porosity of bodies and places. In nature's theater, “our Grandame” seated in retired place, recalls Latona's labor "staying by a Date and Olyf tree" in Delos's empathetic embrace. ${ }^{44}$ Both figures in "trauail" (AM 45) mirror the female poet, "sate" in "the cooling shadow of a stately Elm" (21), engendering her poem. ${ }^{45}$

\section{3. the work of my famely}

The tale of the first family in "Contemplations" informs Bradstreet's family plot. "It pleased God to keep me a long time w $^{\text {th }}$ out a child," Bradstreet writes in her "Book by Any yet unread," "wch was a great greif to me and cost me many prayers \& tears before I obtained one" (AM 44). Samuel was born in 1632 in Bradstreet's home in Cambridge; three brothers and four sisters followed, all raised at the new settlements in Ipswich and Andover, the last two in the series of mobile households marking Bradstreet's "swift and relentless shifting" across the colony. ${ }^{46}$ Recalling Philomel's "feathered crew," she writes, "I Had eight birds

\footnotetext{
${ }^{43}$ Laroche and Munroe, Shakespeare, 18-19 and 33.

${ }^{44}$ Ovid, Metamorphoses, trans. Golding, 6:335-6.

${ }^{45}$ Ovid, Metamorphoses, trans. Golding, 6:336.

${ }^{46}$ Eavan Boland, "Finding Anne Bradstreet," in Green Thoughts, Green Shades: Essays by Contemporary Poets on the Early Modern Lyric, ed. Jonathan F. S. Post (Berkeley: University of California Press, 2002), 176-90 at 178. Bradstreet's frequent allusions to 1 Samuel (see part 4, below) may reflect her identification with Hannah, who delivered Samuel
} 
hatcht in one nest, / Four Cocks there were, and Hens the rest" (SP 245). And, with less creaturely goodwill and a greater will to creative power, she casts her maternal career as protracted labor producing not only bodies but also souls: "as I have brought you into y" world, and $\mathrm{w}^{\text {th }}$ great paines, weaknes, cares, \& fears brought you to this, I now trauail in birth again of you till Christ bee formed in you" (AM 45). Bradstreet's lifelong "trauail in birth" was interrupted by frequent episodes of illness and recovery of which the better part of her "Book" consists. In 1657, for instance, she writes, "I had a sore sicknes, and weaknes took hold of me, $\mathrm{w}^{\mathrm{ch}}$ hath by fitts lasted all this Spring till this 11 . May. yet hath now God given mee many a respite, $\&$ some ability to perform $\mathrm{y}^{\mathrm{e}}$ Dutyes I owe to him, and the work of my famely" (AM 55). The entry is followed two days later by a poem of thanksgiving: "As Spring the winter doth succeed... My Suns return'd $w^{\text {th }}$ healing wings" (AM 56).

This vocational idea of parenting as "the work of my famely" involved Bradstreet, along with most early modern women, in a domestic economy based on exchanges and creativities that were "transcorporeal," in Alaimo's succinct term, situated within the "interconnections, interchanges, and transits between human bodies and nonhuman natures" co-resident in the household ${ }^{47}$ Bradstreet's "Meditations Diuine and morall" is stocked with household stuff, comprising a "home-spun Cloth" (SP 236) of "Commoditys" (Med. 77; AM 41) assisting in the work of her family: bread, bran, honey, beds, brooms, corn, hops, pillows, "horsleach" (Med. 15; AM 22), and many more, are mobilized in domestic activities, from breastfeeding to clothing children to harvesting to preparing food and curatives. Each meditation is grounded in physical sensation, sensory experience, and the praxis of household

after a period of barrenness. Bradstreet's name (Anna) and that of her first born son, Samuel, recall both the story and Hannah's song in 1 Samuel 2:1-10, a model for the Magnificat and for Bradstreet's poetics of private devotion. See Michelle Oscherow, Biblical Women's Voices in Early Modern England (Aldershot: Ashgate, 2009), 45-76. I am grateful to the editor of Criticism for pointing out this allusion.

${ }^{47}$ Alaimo, Bodily Natures, 2. See also Laroche and Munroe, Shakespeare, 20. 
travail. "Diuerse children, haue their different natures," Bradstreet writes, "some are like flesh $\mathrm{w}^{\text {ch }}$ nothing but salt will keep from putrefaction, some again like tender fruits that are best preserued $\mathrm{w}^{\text {th }}$ sugar" (Med. 10; AM 6). Expressing the material imbrication of the maternal body and the suckling infant, Bradstreet writes, "Some children are hardly weaned although the teat be rub' $\mathrm{d} \mathrm{w}^{\text {th }}$ wormwood or mustard, they wil either wipe it off, or els suck down sweet and bitter together." The striking physicality of this figure lingers into its spiritual consequence: "so it is $\mathrm{w}^{\text {th }}$ some christians, let god imbitter all the sweets of this life...yet they are so childishly sottish that they are still huging and sucking these empty brests" (Med. 38; AM 14). Sleep, "the embleam of death" affords the faithful tokens of "not only their death, but their graue, [which] is Liuely represented before their eyes, by beholding their bed" (Med. 71; AM 36). "That house $\mathrm{w}^{\mathrm{ch}}$ is not often swept" figures "that heart $\mathrm{w}^{\mathrm{ch}}$ is not continually purifieing it self": neither is a fit dwelling for "the cleanly inhabitant" or "the spirit of god" (Med. 16; AM 7).

Bradstreet's prose meditations share the poetic process of the "Contemplations," and like the poem, employ and revise the popular Protestant genre of the emblem. Both texts conjure a cultural space where English and American influences intertwine and mingle. In both, Bradstreet's figurations root metaphor in matter: an American ecology redefines and decenters inherited spiritual metaphors, as the orthodoxy of the settlement gives way to the originality of the created (and creative) domestic space. Like any Christian interpreter of the Book of Nature, Bradstreet agrees that "There is no obiect that we see no action that we doe, no good that we inioy, no evill that we feele, or fear, but we may make some spiritvall advantage of all” (Med. 1; AM 3). Certainly Bradstreet's meditations are inspired by emblematic works such as George Wither's Collection of Emblems (1635), with which she shares a small number of images while, tellingly, providing new interpretations of her own 
invention. ${ }^{48}$ Indeed, the originality of Bradstreet's figures and their interpretations is central to her self-avowed purpose: dedicating her "Meditations" to her son, she boldly asserts, "I haue avoyded incroaching upon others conceptions because I would leaue you nothing but myne owne" (AM 1-2). This claim resonates throughout the work in the resourceful, improvisational observations drawn from sensory knowledge and crafted by an independent, creative agent. They are firsthand, insofar as the material hand is intertwined with the technologies of writing and domesticity in the complex systems that they collaboratively create. Bradstreet's “techno-artistic tactics," in William E. Connolly's terms, deploy an originality that accounts for matter and assumes that "complexes of energy" possess vitality and agency. ${ }^{49}$ While her emblems are insistently bound to matter, though, they are also textual rather than visual objects, entwining image and motto of the traditional emblematic form in a single speaking object; a discursive partner that becomes speakable of mute.

These material-discursive emblems and their embedding in the immediacy of place produce a series of embodied figurations that come to life in a new, New World setting. Thus, for instance, when Bradstreet echoes Luke 15:16, "The treasures of the world may well be compared to huskes" (Med. 49; AM 20), she blends biblical grain with the crop indigenous to America, deploying this useful, pliable figure - a new resource with serendipitous associations - with an agricultural precision learned from native American women by pilgrim Bradstreet. ${ }^{50}$ Conveying this flexible crop across the porous threshold of the household, she

\footnotetext{
${ }^{48}$ See George Wither, A Collection of Emblems (London: A. M. for Richard Royston, 1635). Subsequent references appear parenthetically, citing book and emblem number. See Ditmore, "Bliss Lost," on the connection to emblematic practice in "Contemplations," with a glance toward the "Andover Manuscript."

49 Connolly, "'The New Materialism,"” 401.

${ }^{50}$ Luke 15:16 states, "And he would fain have filled his belly with the husks that the swine did eat," a figure revised by Bradstreet's "they that feed upon them [husks], may soon st stuffe their throats, but can not fill their bellys" (AM 20). The King James Bible uses the word "corn" over 100 times, meaning grain. On the maintenance and extraction of corn by Native American and European technologies, see Merchant, Ecological Revolutions, 69-112
} 
conflates the technologies of planting, growing, harvesting with the maternal praxis of childrearing. Children, like corn, must be "produced $\mathrm{w}^{\text {th }}$ much labour," she observes, "[T]he plough of correction must make long furrows on their backs, and the Harrow of discipline goe often ouer [this] sowre land" (Med. 55; AM 28). Thoroughly steeped in matter, this dexterous figuration can accommodate a spiritual sense as well: as "corne till it haue past through the Mill and been ground to powder is not fit for bread," so God "grindes" his servants until they are "fit manchet for his Mansion" (Med. 19; AM 8). Figures, like bodies, are supple, mobile, and agential in Bradstreet's hands.

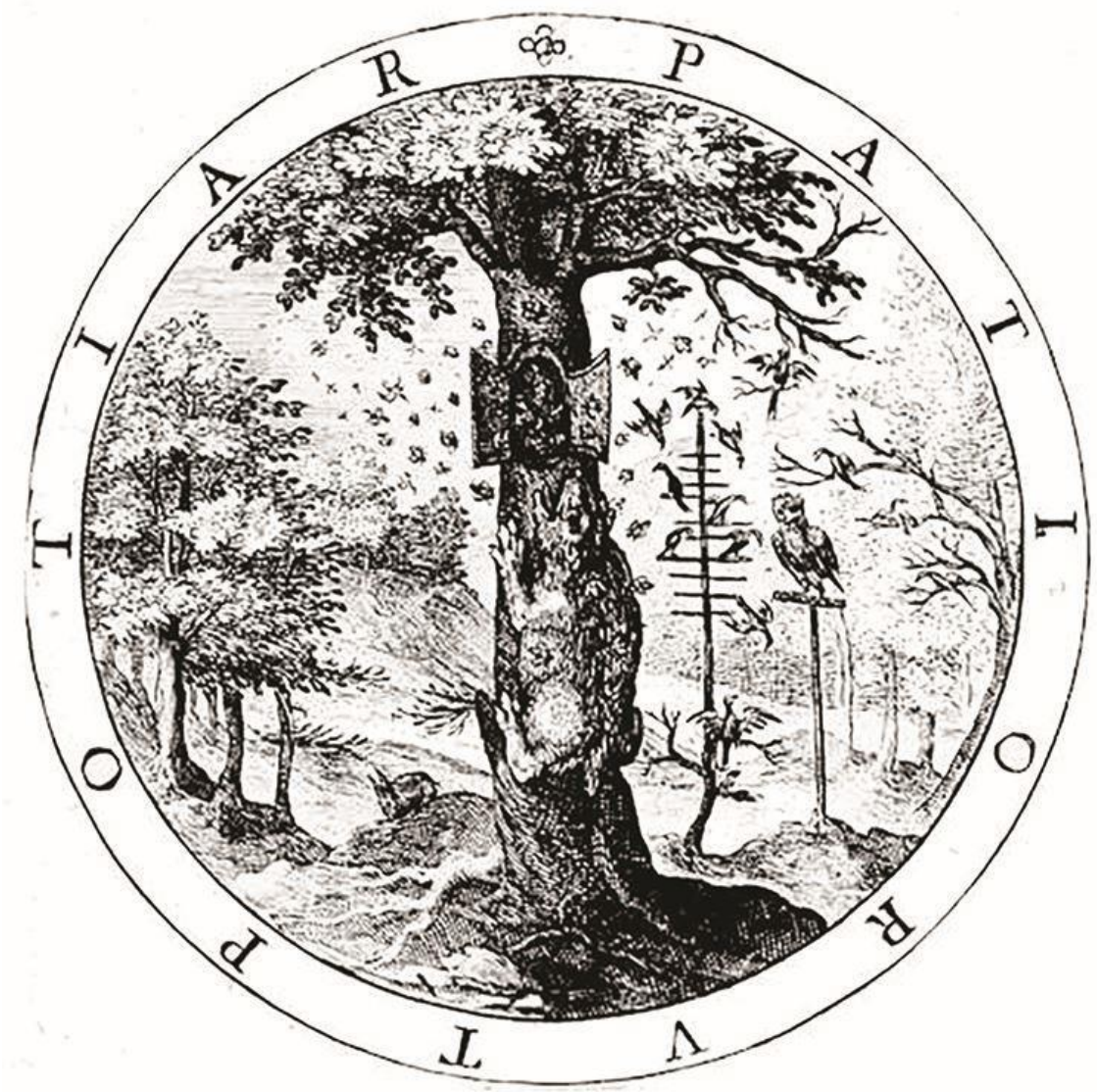

Figure 4. George Wither, A Collection of Emblems (London: A. M. for Richard Royston, 1635), book 1, emblem 28.

In large part, the originality of Bradstreet's engagement with emblematics lies in her decentering of the traditional didacticism of emblems toward what Connolly has called an

and 282, which notes that the crop was planted and processed "primarily by women" in the native ecological system. 
"ethic of cultivation" which emerges not from a "transcendental subject" but from "positive practices of cultivation." Such a position, he explains "gives some priority to the human estate, but it does so by emphasizing our manifold entanglements with nonhuman processes, both within the body and outside humanity." ${ }^{51}$ In exchange for mottos, which summarily enforce a "command or derived morality," to apply Connolly's phrase, Bradstreet pursues an actively interrogatory process, eschewing simple morals and enfolding meaningssometimes occluded — in the agential mesh of the material world. ${ }^{52}$ Wither's motto, "No Inward Griefe, nor outward Smart, / Can overcome a Patient-Heart” (1:28), for example, glosses the image of a tree over which human engineering has exercised command: "Some Trees, when Men oppresse their Aged Heads, / (With waighty Stones) they fructifie the more" (see figure 4). Thirty lines of verse compare this oppression to that of the Jews in Egypt, the persecutions of the early Christians by Rome, and "a thousand Suff'rings" and "Torment, which our Flesh can feel," closing with the instructive couplet, "Where, Honest Mindes, and Patient Hearts, are Mates; / They grow victorious, in their Hardest-Fates." Applying motto to image, the despotic mastery of nature that produces a fruitful tree commands patience against traitorous passions within and tyrannical oppressions without. Wither's application is far from organic - it would be absurd in this context to ponder the "Inward Grief" or "outward Smart" of the literal tree_-and its intellectual contrivance enforces a lesson, a "waighty Stone," on the reader's mind. This overlaying of conceit on matter is the primary method of Wither's visual emblems: for instance, the motto "Time, is $a$ Fading-flowre, that's found / Within Eternities wide round" (2:40) (see figure 5) shows the erect circle of the serpent eating his tail in front of a natural landscape, the "Fading-flowre"

${ }^{51}$ Connolly, "'The New Materialism," 401. See also Connolly, Fragility of Things, 98-139.

${ }^{52}$ Connolly, "'The New Materialism," "400-401. 
centered precisely in the self-consuming ring. The world is a backdrop for human activity in Wither's humanist collection.

When Bradstreet engages the image of the fruitful tree," however, she practices a method that is less an overlaying than an enmeshing, less contrivance than cultivation:

We see in orchards, some trees soe fruitfull, that the waights of their Burden, is the breaking of their Limbes, some again, are but meanly Loaden, and some haue nothing to shew but leaues only, and some among them are dry stocks, so

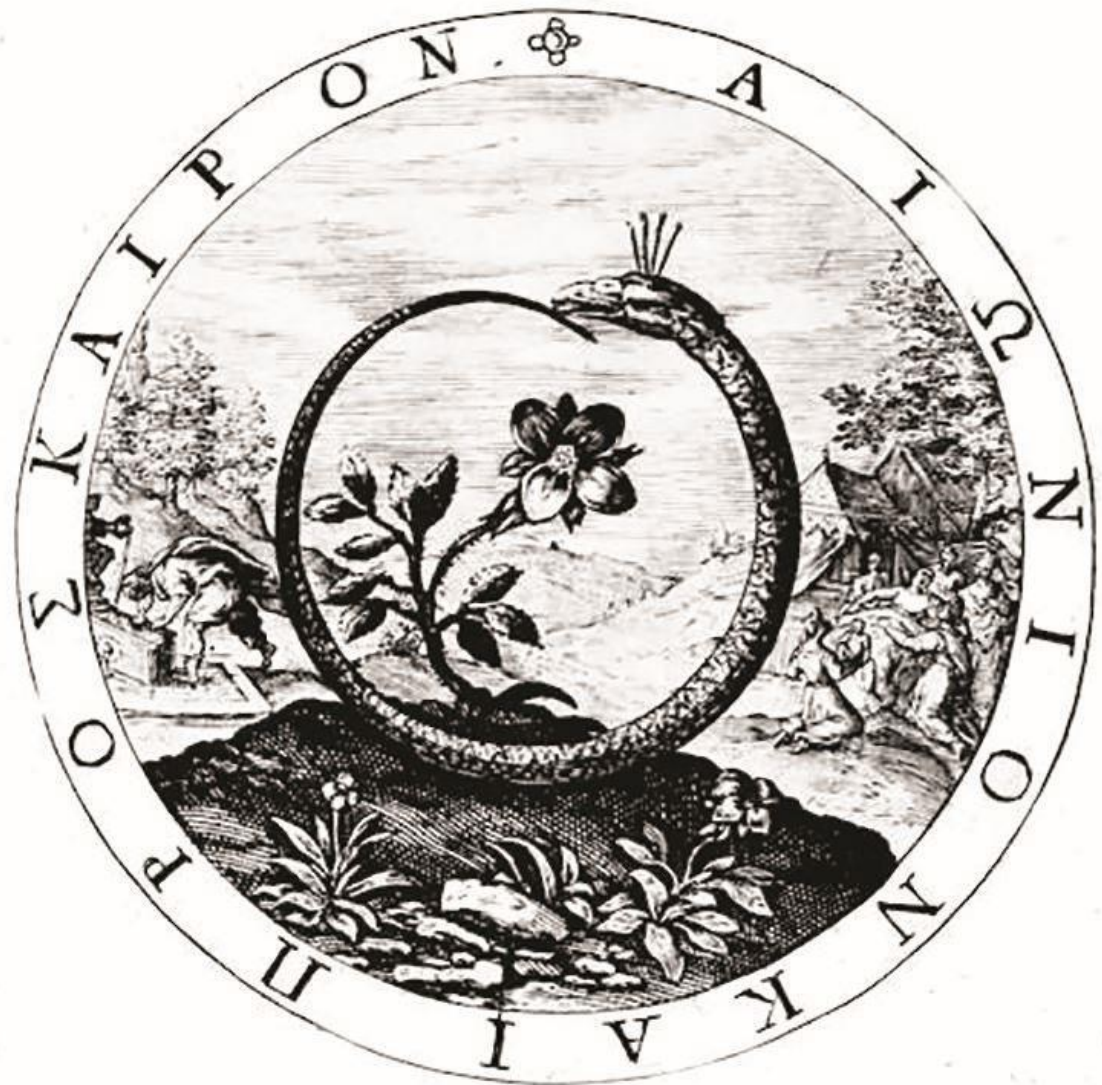

Figure 5. Wither, A Collection of Emblems, book 2, emblem 40.

it is in the church $\mathrm{w}^{\mathrm{ch}}$ is gods orchard, there are some eminent christians, that are soe frequent in good dutys, that many times the waight therof impares both their bodys and estates, and ther are some (and they sincere ones too) who haue not attained to that fruitfullnes, altho they aime at perfection. And again 
there are others that haue nothing to commend them, but only a gay proffession, and these are but Leauie christians, $\mathrm{w}^{\mathrm{ch}}$ are in as much danger of being cut down as the dry stock, for both cumber the ground. (Med. 64; AM 30-31)

Enlarging the singular emblematic tree to an orchard —indeed, resurrecting the apple orchard where the speaker finds herself in "Contemplations"-Bradstreet embeds her own and her reader's eye within a complex network of natural phenomena, and extends the multiplicity of the natural world to account for the diversity of "gods orchard," the church. This is not an act of stewardship but of partnership. Bradstreet's "Meditations" are enmeshed with their compiler in the web of interconnections and material exchanges of which the colonial household consists. Entering into this textual space, readers are engulfed by the complexity of the created world; a swirling, shifting, multi-layered universe - a fleeting household - in which we, the author, and nonhuman agents are entangled. Neither transcendental prime mover nor spider at the center of her web, Bradstreet embraces an ethic of cultivation that energizes the vital affiliations within and between human and nonhuman systems. ${ }^{53}$

If there is one lesson to be taken from Bradstreet's "Meditations," it resides less in didactic singularity than in the delight and wonder that the writer finds in complexity, of the world and of the self. Bradstreet fills the "spacious roome" (Med. 51; AM 22) of her soul and of her text with subtly drawn figures of wondrously diverse materiality. Advancing these intricate systems of interconnection as fundamental to creation, moreover, the "Meditations" situates these networks both within the individual body and as a political principle binding the social self to others. The daughter, wife, and mother of judges, Bradstreet demonstrates

\footnotetext{
${ }^{53}$ As early as 1434, Leon Battista Alberti's Della famiglia employed the spider in his web as a figure for the male householder's domestic government: see The Family in Renaissance Florence: I Libri della famiglia, Book Three, trans. Renée Neu Watkins (Long Grove, IL: Waveland Press, 1994), 76.
} 
her facility with legal discourses in her complication of the commonplace of the body politic. ${ }^{4}$ "As man is called the little world," she writes, "so his heart maybe cal'd the little Commonwealth: his more fixed and resolued thoughts are like to inhabitants, the slight and flitting thoughts are like passengers, that trauell to and fro continually." Set before the "Court of iustice," the conscience, a "Judg, whom no bribes can pervert," absolves or condemns. The Christian heart - a diverse nation of firm and fleeting thoughts, of citizens and strangersmust "carry a certificate from the court of conscience," like a writ of safe conduct, to "the throne of grace" (Med. 62; AM 29). So attuned is Bradstreet to domestic economies, both micro- and macrocosmic, that she renders "mutuall Commerce" between nations as a figure for the interdependencies that pervade her work: "God hath by his prouidence so ordered, that no one Covntry hath all Commoditys $w^{\text {th }}$ in it self, but what it wants, another shall supply...As it is $w^{\text {th }}$ Covntrys so it is with men" (Med. 77; AM 41). ${ }^{55}$

While Bradstreet's resourceful interpretations create and celebrate productive affiliations, the risks that attend her movement from orthodoxy to originality rise to the surface in her "Book by Any yet unread." The "Book," like the "Meditations," represents itself as a mother's legacy, one that also stakes out original generic and creative grounds: in the dedication to her children, she writes, "[I] thought $\mathrm{y}^{\mathrm{t}}$ best, whilst I was able, to compose some short matters (for $\mathrm{w}^{\mathrm{t}}$ else to call $\mathrm{y}^{\mathrm{m}} \mathrm{I}$ know not) and bequeath to you, that when I am no more $\mathrm{w}^{\text {th }}$ you, yet I may bee dayly in $\mathrm{y}^{\mathrm{r}}$ remembrance" (AM 43). Her method, she explains, will be to "begin $w^{\text {th }}$ Gods dealing $w^{\text {th }}$ me from my childhood to this Day" (AM 44). She recounts the sins of a 6-year-old Bradstreet, her affliction at 16 with smallpox (brought on by pride and vanity), her marriage, her arrival in America, and the birth of her first child (AM

\footnotetext{
${ }^{54}$ Bradstreet's son Dudley was justice of the peace in Andover. During the witch trials at Salem in 1692 he refused to issue warrants for the accused. Thomas Dudley and Simon Bradstreet were both governors of the Massachusetts Bay Colony.

${ }^{55}$ For Bradstreet's overtly political meditations, see also Meds. 26, 34 and 70, AM 11, 13, and 35 , respectively.
} 
44-5). But Bradstreet's autobiography is primarily a spiritual journey fraught with self-doubt, temptations, falls, and recoveries, and one inextricably tied to the body. This embodied struggle between faith and doubt—situated in the flesh as it approaches death—tries, with only partial success, to calm the author's fear that she embraces "more sence then faith" (Med. 13, AM 7).

Bradstreet's "Book by Any yet unread" is a book of the body, and it is a book of memory - but one that understands remembrance as a bodily function co-constituted with the materiality of place. Read in this way, Bradstreet's manuscript embodies, so to speak, the interactions and exchanges of creatures across porous temporal borders. Bradstreet as subject materializes in the multiplicity of her interchangeable episodes of sickness and recovery; episodes that co-exist spatially in a pliable temporality. In the dedicatory poem to her children, bodies congregate across the porous threshold between life and death, between presence and absence:

This Book by Any yet unread,

I leaue for you when I am dead,

That being gone, here you may find

What was $\mathrm{y}^{\mathrm{r}}$ liuing mothers mind. $\quad(\mathrm{AM} 43)$

The "Book" weaves a web of connections tying the body, an admixture of matter and belief, to the agencies of the world that Bradstreet prepares to leave behind.

In a catechism performed by one - as she puts it, "I haue argved thvs with myself" (AM 46) — Bradstreet tests the foundations of her Puritan faith. She confesses, "I haue often been perplexed $\mathrm{y}^{\mathrm{t}} \mathrm{I}$ haue not found that constant Joy in my pilgrimage and refreshing, $\mathrm{w}^{\mathrm{ch}} \mathrm{I}$ supposed most of the servants of God haue" (AM 46). Her "sinkings \& droopings" (AM 46) shake her confidence in election and challenge the value of spiritual counsel. "Authority $\mathrm{w}^{\text {th }}$ out wisedome," she writes in her meditations, "is like a heauy axe, $\mathrm{w}^{\text {th }}$ out an edg fitter to 
bruise, then polish" (Med. 12; AM 6), and she wonders in her "Book," "how should I know he is such a God as I worship...tho: this hath thovsands of Times been suggested to me" (AM 47). As in the "Meditations," she arrives at assurance through firsthand, phenomenal experience of the material world — "That there is a God I see"- and the gloss provided by the Word (AM 47). Despite her father's condemnation of "the Old Idolitry and superstition of Popery," Bradstreet is not afraid to ask, "Why may not $\mathrm{y}^{\mathrm{e}}$ popish Religion bee $\mathrm{y}^{\mathrm{e}}$ right?" (AM 47). Her engagement with the specter of Catholicism, however, leads her to a threshold not easily crossed. Although she admits, "They haue the same God, the same christ, $\mathrm{y}^{\mathrm{e}}$ same word: They only enterprett it one way, we another" (AM 47-8), this momentary fellowship is short lived when Bradstreet quickly reminds herself of " $y$ e vain fooleries, that are in their Religion: together $\mathrm{w}^{\text {th }}$ their lying miracles, and cruell persecutions of the Saints" (AM 48).

If the daring with which Bradstreet poses the Catholic question is undermined by the intolerance with which it is answered, this orthodox formulation is telling when compared to her interactions with a more diverse, less univocal world, both natural and cultural, elsewhere in her corpus. Here, at the limits of Bradstreet's ability to celebrate the multiplicity of opinions and beliefs, she becomes her father's daughter, accepting and agreeing with the dominant derision of Catholic "fooleries." Indeed, it would misrepresent the challenge posed by her confessions to view Bradstreet as subversive of Puritan orthodoxy: rather, her goal is to destabilize its firm borders, revealing them as porous; admitting a space for interrogation, creativity, and originality. As a mother's legacy written to instruct her children after her death, the purpose of the "Book," ideally, is not only to present but, more importantly, to resolve the author's history of doubt and self-doubt. Yet this conformist episode is exceptional in the manuscript in two respects. First, it is uncharacteristically imprecise and literal: devoid of figuration—-lacking imagination and autonomy — the passage simply calls forth, as if by rote, the predictable Catholic crimes. Second, Bradstreet's treatment of the 
Catholic threat admits her recognition, stated then squelched, that Puritan truth and Catholic error involve identical origins and practices: "They only enterprett it one way, we another." At this interpretive crux, the chiasmic bond between truth and error is revealed, exposing an entanglement that troubles both terms.

While interpretation is the root of error - and, vexingly, the foundation of truth - it is also, for Bradstreet, a prompt to creativity from which faith can spring. Confronting the most challenging of doubts, accordingly, Bradstreet relies on her imaginative capacity to figure human imbrication with the complexity of the nonhuman: "Many times hath Satan troubled me," she writes, "concerning $y^{\mathrm{e}}$ verity of $\mathrm{y}^{\mathrm{e}}$ Scriptures, many times by Atheisme, how I could know whether there was a God, I never saw any miracles to confirm me, and those $\mathrm{w}^{\text {ch }}$ I read of how did I know but they were feigned." Her counter-argument resurrects the vibrant imagery of the "Meditations": "That there is a God my Reason would soon tell me by the wondrous workes that I see, the vast frame of the Heaven \& $y^{\mathrm{e}}$ Earth, the order of all things...the dayly providing for this great hovshold vpon $\mathrm{y}^{\mathrm{e}}$ Earth" (AM 47). Vitally engaged in the natural and cultural order of things, Bradstreet is assured that there is "an Eternall Being" (AM 47) by the plentiful store of the earth's household, preserved and managed by a diligent householder; a domestic being very much like she herself.

Bradstreet's "Andover Manuscript" builds a household that is both intimate and expansive - and one that, finally, is fleeting. On July 12, 1666, Bradstreet's son Simon recorded:

my father's house at Andover was burnt, where I lost my Books and many of my clothes, to the valieu of 50 or 60 pounds at least; The Lord gave, and the Lord hath taken, blessed bee $\mathrm{y}^{\mathrm{e}}$ name of the Lord. Tho: my own losse of books (and papers espec.) was great and my fathers far more being about 800 , yet $\mathrm{y}^{\mathrm{e}}$ Lord 
was pleased gratiously many wayes to make up $\mathrm{y}^{\mathrm{e}}$ same to us. It is therefore good to trust in the Lord. ${ }^{56}$

Her son's obedient acceptance of God's will is echoed at the close of Bradstreet's poem "vpon $\mathrm{y}^{\mathrm{e}}$ burning of our house," copied by Simon in the "Andover Manuscript" from "a loose Paper": "Thou hast an house on high erect," she writes, "ffram'd by that mighty Architect / $\mathrm{W}^{\text {th }}$ glory richly furnished." She concludes with a hope for reconciliation which, one feels, she has not yet found; another struggle to calm the rising heart: "The world no longer let me Love, / My hope, and Treasure lyes Above" (AM 67). Before this mournful gesture, Bradstreet conducts the reader through the memory palace of her ruined home; a pilgrimage that recalls, now in a somber tone, the path followed by the speaker of "Contemplations," one that reaffirms the household as "what I count the best" (24):

When by the Ruines oft I pass,

My sorrowing eyes aside did cast,

And here and there $\mathrm{y}^{\mathrm{e}}$ places spye

Where oft I sate, and long did lye,

Here stood that Trunk, and there $\mathrm{y}^{\mathrm{t}}$ chest;

There lay that store I covnted best

My pleasant things in ashes lye

And them behold no more shall I. (AM 66)

\footnotetext{
${ }^{56}$ Rev. Simon Bradstreet, "Memoires," quoted in Ellis, ed., Works, lxii. Bradstreet gives the date as July 10. Simon Bradstreet's library was unusually large. See Elizabeth Sauer, "Book Passages and the Reconstruction of the Bradstreets' New England Library," in Women's Bookscapes in Early Modern Britain: Reading, Ownership, Circulation, ed. Leah Knight, Micheline White, and Elizabeth Sauer (Ann Arbor: University of Michigan Press, 2018), 5976.
} 
Exiled from her home, Bradstreet remains unable to leave it fully behind. Although she laments that "My papers fell a prey to th' raging fire" (SP 191), the "Andover Manuscript" is a miraculous survivor and witness to the rich, complex networks of affect and acts binding the family to each other and to this beloved space. ${ }^{57}$ Her entanglement-a symbiotic, mutual materiality-leads Bradstreet's speaker finally to address the house as if it were a family member who took part in the shared activities of everyday life:

Vnder thy roof no gvest shall sitt,

Nor at thy Table eat a bitt.

No pleasant tale shall 'ere be told,

Nor things recovnted done of old.

No Candle 'ere shall shine in Thee,

Nor bridegroom's voice ere heard shall bee.

In Silence ever shalt thou lye;

Adeiu, Adeiu; All's vanity.

(AM 67)

The care and sorrow with which she consigns the ruined frame of her home to earth amounts to an elegy; a funeral song for the "dear remains" of matter (SP 239) and for her own "Clay house" of a body, "mouldring away" (AM 98).

\section{4. a white stone}

\footnotetext{
${ }^{57}$ With the exception of this poem and the valedictory "As weary pilgrim," which is written in Bradstreet's hand on the last page of the volume, following 28 blank leaves (AM 98-9), all the entries in AM predate the fire. Following a poem dated September 3, 1662, Simon writes, "This was the last Thing written in that Book by my dear \& hon ${ }^{\mathrm{d}}$ Mother" (AM 66).
} 


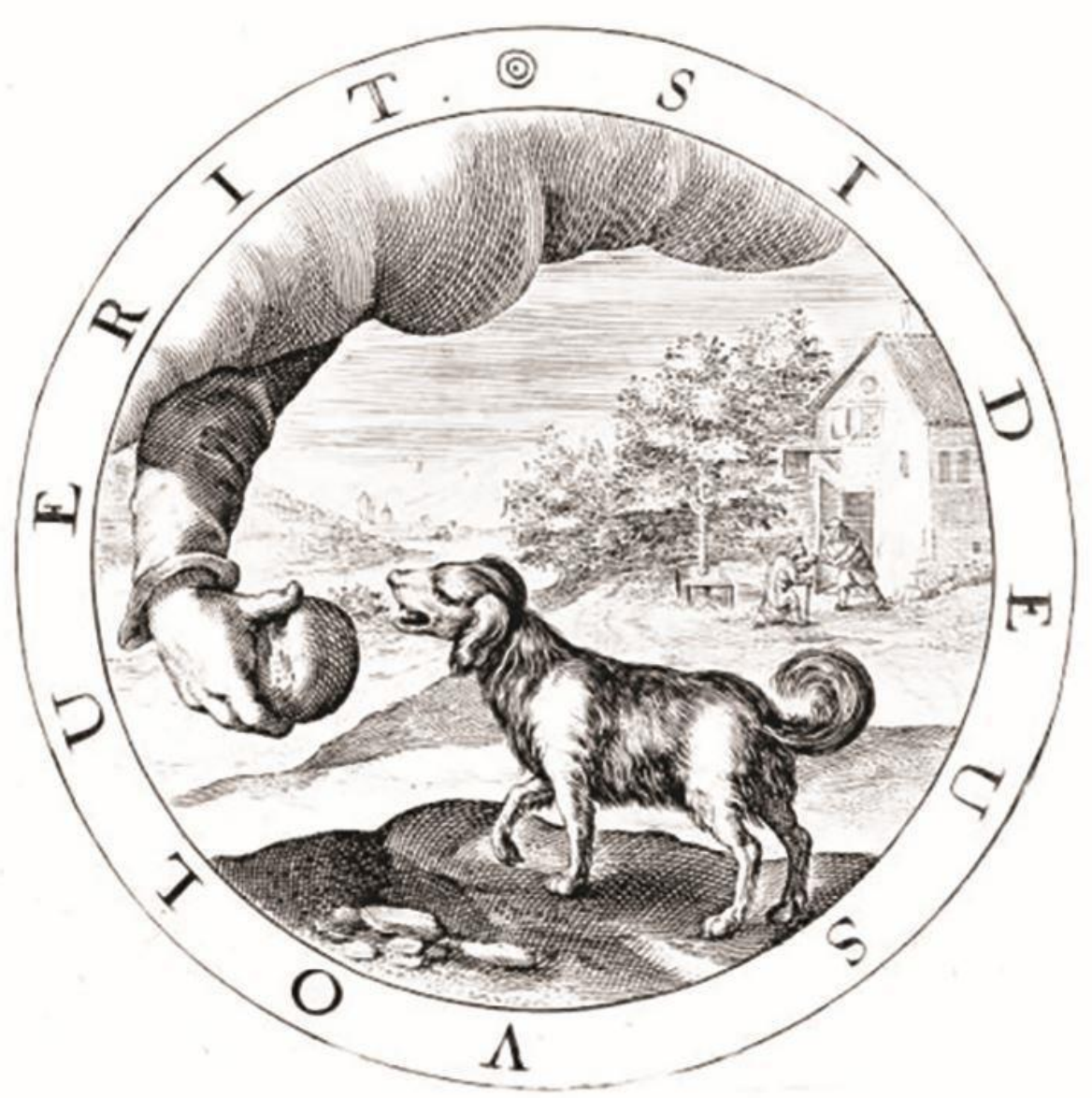

Figure 6. Wither, A Collection of Emblems, book 4, emblem 47.

In an image that resonates with the posthumanist concern for "companion species," Wither depicts the arm of God stretching from the heavens to provide a loaf of bread to a "grinning-dog" (4:47) (see figure 6) ${ }^{58}$ The scene is set in a clearing: in the background a householder shares his bread with a beggar just outside the door of his (not immodest) home. The inspiration for the emblem is David's castigation in Psalm 59 of his enemies, who "grinne lyke a dogge, and runne about through the citie," and, remarkably, "speake with theyr mouthe." ${ }^{59}$ Wither turns the image toward a warning to the faithful "to beware / Who bound

\footnotetext{
${ }^{58}$ See Donna J. Haraway, When Species Meet (Minneapolis: University of Minnesota Press, 2008); and Haraway, Companion Species Manifesto.

${ }^{59}$ Church of England, Psalter or Psalmes of Dauid (London: Edward Whitechurch, 1553), D5 ${ }^{\mathrm{v}}$.
} 
God's Mercie; and... shut out some / From hope of Grace." God, "who as hee lists, bestowes his owne...Doth offer to the Dogges, the Childrens bread."

Although the immediate source for the image lies in the Psalms, the emblem's unfolding alludes to a New Testament verse which was a favorite of Bradstreet's. In Revelation 2:17, John writes, "To him that overcometh will I give to eat of the hidden manna, and will give him a white stone, and in the stone a new name written, which no man knoweth saving he that receiveth it." The verse and its Puritan exegesis underwrite the confident statement in Bradstreet's "The Flesh and the Spirit," where the speaker affirms, "The hidden Manna I doe eat, / The word of life it is my meat" (SP 231). It also occurs in a moment of distressing uncertainty in her "Book":

I haue somet[imes] tasted of $\mathrm{y}^{\mathrm{t}}$ hidden Manna $\mathrm{y}^{\mathrm{t}} \mathrm{y}^{\mathrm{e}}$ world knowes not, \& haue sett vp my Ebenez ${ }^{\text {er }}$, and haue resolved $w^{\text {th }}$ my self $y^{t}$ against such a promis, such tasts of sweetnes, $\mathrm{y}^{\mathrm{e}}$ Gates of Hell shall neuer preuail. Yet haue I many Times sinkings \& droopings, and not enjoyed that felicity that somet[imes] I haue done. (AM 46)

With none of the boldness of Wither's God, whose fleshy arm parts the clouds to make visible the hidden manna, Bradstreet's God is one who too often conceals himself. "Beclouded was my Soul $w^{\text {th }}$ fear," she writes during a fever, "Hide not thy face from me" (AM 49). Indeed, Bradstreet's embodied, occluded struggle between faith and doubt responds to William Perkins's Puritan gloss of the hidden manna and its attendant white stone, which argues that "the church in Rome is deceiued, who make Visibilitie the marke of Gods church: for Gods church is a companie of men which beleeue." ${ }^{\prime 60}$ Despite the exuberant visibility of Wither's instructional emblem, his warning against presumption echoes Perkins's similar

${ }^{60}$ William Perkins, A Godly and Learned Exposition or Commentary on First Three Chapters of the Revelation, 2nd edition, ed. Robert Hill and Thomas Pierson (London: Adam Islip for Cuthbert Burbie, 1606), 132. 
caution to the faithful: the judgment of salvation "belongs to God, not to man saue onely the man himselfe." ${ }^{61}$ God bestows his own, as Wither puts it, "who as hee lists." Or as Bradstreet worries, "Why may not $\mathrm{y}^{\mathrm{e}}$ popish Religion bee $\mathrm{y}^{\mathrm{e}}$ right?"

Bradstreet's coupling of the hidden manna with a stone memorial, Ebenezar, responds to the coupling of the hidden manna with the white stone in Revelation 2:17. The episode to which she alludes follows Samuel's defeat of the Philistines: "Then Samuel took a stone, and set it between Mizpeh and Shen, and called the name of it Ebenezer, saying, Hitherto hath the LORD helped us" (1 Samuel 7:12). The allusion reimagines the spiritual topography of Bradstreet's struggle as a literal, geographical site — a battlefield — on which she erects her commemorative "stone of help." ${ }^{2}$ It is in the context of commemoration, I suggest, that Bradstreet's only direct citation of Revelation's white stone occurs. In the last stanza of “Contemplations," Bradstreet departs from her rime royale meter with a stanza of four heroic couplets, "in the manner," as Ditmore observes, "of the Tenth Muse poems":63

O Time the fatal wrack of mortal things,

That draws oblivions curtains over kings.

Their sumptuous monuments, men know them not,

Their names without a Record are forgot,

Their parts, their ports, their pomp's all laid in th' dust

Nor wit nor gold, nor buildings scape times rust;

But he whose name is grav'd in the white stone

Shall last and Shine when all of these are gone. (33)

\footnotetext{
${ }^{61}$ Perkins, Godly and Learned Exposition, 131.

${ }^{62}$ In Hebrew, "Eben-ha-Ezer," literally "stone of help." The allusion reiterates Bradstreet's apparent self-identification with the story of Samuel and Hannah.

${ }^{63}$ Ditmore, "Bliss Lost," 148.
} 
As the closing figure of "Contemplations," the white stone is an overdetermined sign, like the apple tree at the poem's opening. Perkins uncovers the probable origin of this resourceful piece of matter before unpacking its complex cluster of material and spiritual energies:

Here Christ borroweth a comparison from the custom and manners of the gentiles...A white stone was of great vse among them: For first, the iudge in giuing sentence, vsed white stones, and blacke stones: the giuing of a white stone was a token of absolution; the giuing of a blacke stone a signe of condemnation. ${ }^{64}$

The white stone resuscitates custom in "Contemplations" toward life rather than death. Here, against the monuments "laid in th' dust," the name "grav'd in the white stone" signals, as Perkins puts it, "the vnion of Absolution and Regeneration." 65 This memorial resonates with the continual renewal and rebirth of nature against which Bradstreet's speaker contrasts with the frailty of the human, who "remains," like a ruined monument, "where once he's laid" (18). Yet it transmutes natural regeneration by reasserting the possibility, discarded earlier in the poem, that cultural memory, the remembrance of "men in being," is a form of renewal: "When present times look back to Ages past, / And men in being fancy those are dead, / It makes things gone perpetually to last" (10). The rebirth promised by the figure, moreover, moves the speaker from solitude to fellowship. The verse contains a two-fold commandment, Perkins writes: "First, that all men in Gods church are bound in conscience to frequent Sermons," and secondly, "men are inioyned the reading of the word \& hearing of it read, not only publickly but also priuately in their families." ${ }^{966}$ As the monument abruptly materializes in a natural setting where the specifically maternal body is thoroughly entangled, it mixes with and reaffirms the creative and procreative agencies of the river and the nightingale. The

\footnotetext{
${ }^{64}$ Perkins, Godly and Learned Exposition, 131.

${ }^{65}$ Perkins, Godly and Learned Exposition, 131.

${ }^{66}$ Perkins, Godly and Learned Exposition, 127-8.
} 
white stone returns the speaker to the work of the family; the maternal, spiritual "trauail in birth" that sustains the Puritan household.

The white stone is apt to the purpose and process of "Contemplations" in its merger of matter and discourse, object and text, and most signficantly, in its blending of maternity and monumentality. ${ }^{67}$ Its figurative placement amid the ruins of sumptuous monuments argues that this stone is an Ebenezer; a situated memorial that carries a name. The speaker happens upon this speaking stone as one might happen on a tombstone in a quiet rural graveyard. The white stone with a name "grav'd"- notice, for Bradstreet, not a "new name"- serves as a token of hope for the speaker, while its material placement in Several Poems suggests plural meanings. "Contemplations" appears in the collection before Bradstreet's poems "found among her Papers after her Death, which she never meant should come to publick view" (SP 237), implying that the structure of the volume and the poem's location were by Bradstreet's design. The poem is printed immediately following a section carrying the running title, “Elegies and Epitaphs" (SP 203-220), a grouping expanded in Bradstreet's second edition to include the Tenth Muse poems — elegies for Sir Philip Sidney, Guillaume du Bartas, and Queen Elizabeth I, and David's lamentation for Saul—plus memorials for Bradstreet's parents, Thomas and Dorothy Dudley. The group ends with the "Epitaph" for Dorothy Dudley, printed across the page from "Contemplations," on the left open leaf with "Contemplations" commencing on the right. The epitaph for Dorothy Dudley and its position defy the polarization of public and private poems often advanced in readings of Bradstreet's works: if Governor Dudley is a public figure, so too, Bradstreet argues, is the "worthy Matron," Dorothy. The return to heroic couplets in the last stanza of "Contemplations" is

\footnotetext{
${ }^{67}$ See Branka Arsic, "Brain-ache: Anne Bradstreet on Sensing," ELH 80.4 (Winter 2013), 1009-43 at 1030, for a related reading of "The Flesh and the Spirit."
} 
specifically a return to the meters of Bradstreet's "Elegies and Epitaphs," the form commemorating queens and governors, poets and mothers.

Bradstreet's white stone emerges from the biblical source but she redirects the figure from orthodoxy to originality, erecting a memorial to a creative matriarch whose virtues are shared by the maternal figures of "Contemplations" and exemplified in the domestic dexterities of the "Meditations." She was "A friendly Neighbor, pitiful to poor, / Whom oft she fed, and clothed with her store;" a woman who followed the commandments of Revelation 2:17:

A true Instructor of her Family,

The which she ordered with dexterity.

The publick meetings ever did frequent,

And in her Closet constant hours she spent;

Religious in all her words and wayes,

Preparing still for death, till end of dayes. (SP 220)

Sprung up not in the graveyard but in the woods of "Contemplations," Dorothy Dudley's monument joins mother and daughter across the porous border between life and death, remembering the death of one and anticipating the death of the other.

Bradstreet anticipated her death in numerous passages and poems that serve as selfauthored epitaphs. In an early poem, "Before the Birth of one of my Children," she urges her husband, "Look to my little babes my dear remains," and concludes by erecting not a sculptural monument but a textual one:

And if chance to thine eyes shall bring this verse,

With some sad sighs honour my absent Herse;

And kiss this paper for thy loves dear sake,

Who with salt tears this last Farewel did take. (SP 393-4) 
While death initiates the most profound and undeniable blending of body and earth,

Bradstreet's elegies are remarkable for their detailed records of corporeality and their

author's fervent embrace of matter. In elegies for three grandchildren-written "with troubled heart \& trembling hand" for infants who were "my hearts too much content" (SP 248-9)—she struggles to submit to the will of a God who uproots newly-planted shoots:

By nature Trees do rot when they are grown.

And Plumbs and Apples throughly ripe do fall.

And Corn and grass are in their season mown.

And time brings down what is both strong and tall.

But plants new set to be eradicate.

And buds new blown, to have so short a date.

Is by his hand alone that guides nature and fate. (SP 248)

Her elegies for political figures find the poet at the graveside addressing "a coterie of ghosts," as Catherine Gray puts it: "presenting my Lamentations" at Thomas Dudley's hearse (SP 219), "bleating" before the hearse of Queen Elizabeth (TM 200), and appending to each an "Epitaph" which robs the grave of carved inscriptions replaced by her printed monuments. ${ }^{68}$ Bradstreet's epitaph for her father ends equivocally, “And when his time with years was spent, / If some rejoyc'd, more did lament" (SP 219). Yet it seems to be an improvement on both the epitaph reportedly carved on his monument in Roxbury (see figure 7)—_Here lies Thomas Dudley, that trusty old stud,/ A bargain 's a bargain, and must be made good"—-and

${ }^{68}$ Catherine Gray, Women Writers and Public Debate in 17th-Century Britain (London: Palgrave, 2007), 143-81. See also Katherine Gillespie, "'This briny ocean will o'erflow your shore': Anne Bradstreet's 'Second World' Atlanticism and National Narratives of Literary History," Symboisis 3.2 (1999), 99-118; and Nancy E. Wright, "Epitaphic Conventions and the Reception of Anne Bradstreet's Public Voice," Early American Literature 31 (1996), 243-62. 
his self-authored epitaph, found in his pocket after his death, which resoundingly concludes, “My Epitaph’s, I Dy’ed no Libertine!”69

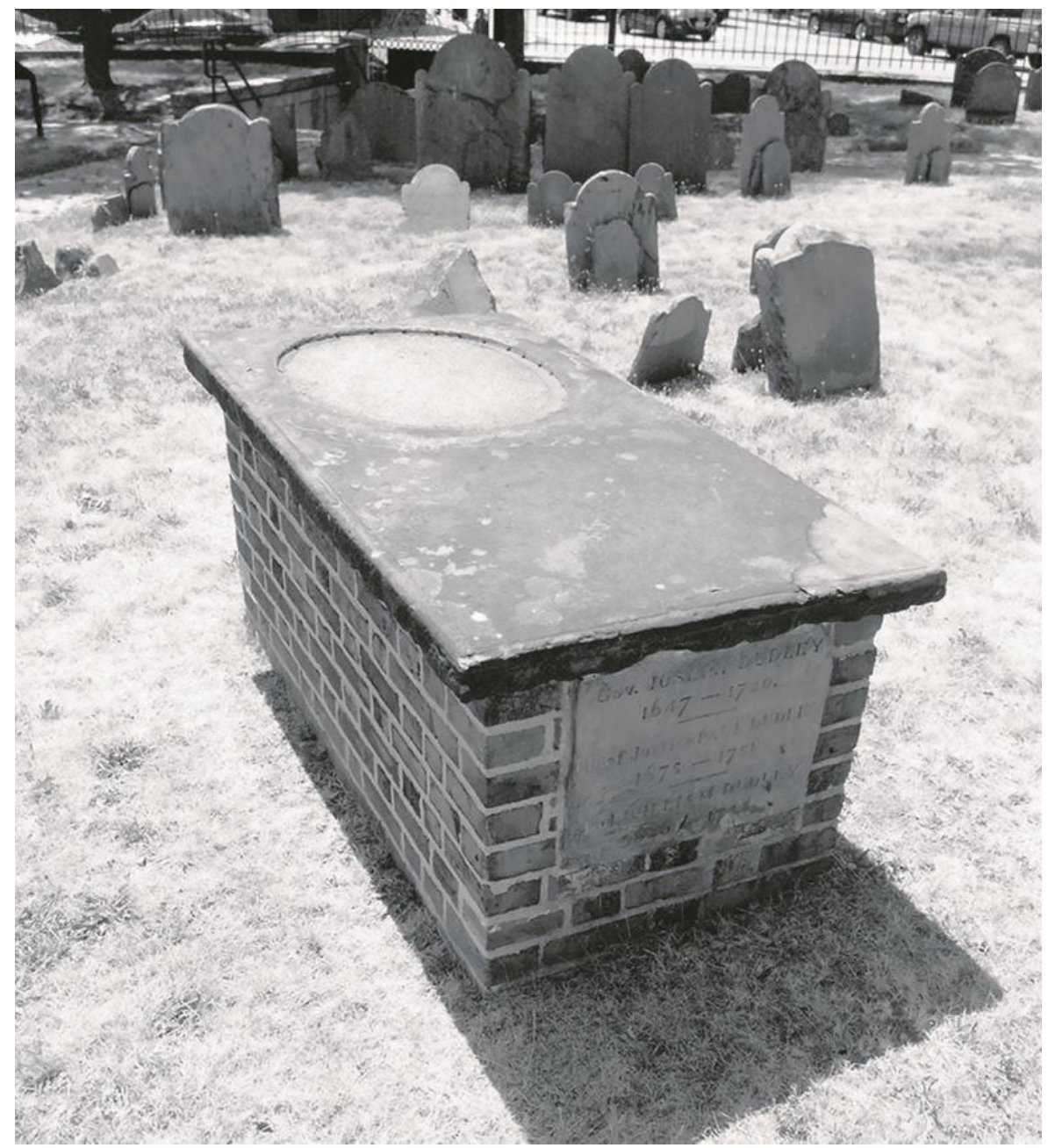

Figure 7. Monument for Thomas Dudley, after 1653. Eliot Burying Ground, Roxbury, MA. Photograph by Iman Khadija Berrahou.

Although Bradstreet prefaces her "Epitaph" for her mother with the guarantee, "Here lyes," Dorothy Dudley's grave was not marked. Nor was her daughter's: the "absent Herse" Bradstreet envisioned was realized after her death. In his will, Dudley asked to be buried beside his first wife, Dorothy, and although there is no record of her burial, Dudley's

${ }^{69}$ See Jones, Life, 417-19; and Ellis, ed., Works, 1vi. Dudley's monument appears to have been among the first erected in the colony. The original pewter plaque containing the epitaph has been lost. 
interment at Roxbury confirms that she too was buried there. The white stone engraved with her name is a piece of matter that survives only in the material text and the mind's eye.

The materiality of the absent grave - a white stone glimpsed in the wilderness, a tomb displaced by text, time, and distance — is remarkably glossed in Bradstreet's epitaph for Queen Elizabeth, written in the year of her mother's death (TM 203) and printed a halfcentury after the monarch's. It is the first of two epitaphs Bradstreet offers for the queen, as though Elizabeth's body lies not only in Old England — so far away as to be invisible—-but also in Bradstreet's tangible memorial erected in New:

Here sleeps THE Queen, this is the royall bed

O' th' Damask Rose, sprung from the white and red,

Whose sweet perfume fills the all-filling aire,

This Rose is withered, once so lovely faire,

On neither tree did grow such Rose before,

The greater was our gaine, our losse the more. (TM 203)

Subtly, roses spring from a marble bed with a scent that embraces two worlds. These regenerative flowers - poetic posies - spring up anew in the earth of America.

Anne Bradstreet left no will: she died twenty-five years before her husband and had no other property to bequeath but her mother's legacies in manuscript. ${ }^{70}$ The preservation of

\footnotetext{
${ }^{70}$ Simon Bradstreet (d. 1697) was buried in Salem; his second wife, Ann Gardner, was buried with him in 1713. His Latin epitaph was copied from the monument in the late-eighteenth century; based on the copy, it was replaced with a copper plaque in 1917 which is still extant. In 1793/4, the tomb was sold and the Simon's and Ann's remains were exhumed "and thrown into a hole not far off." See Ellis, ed., Works, lxxi.
} 


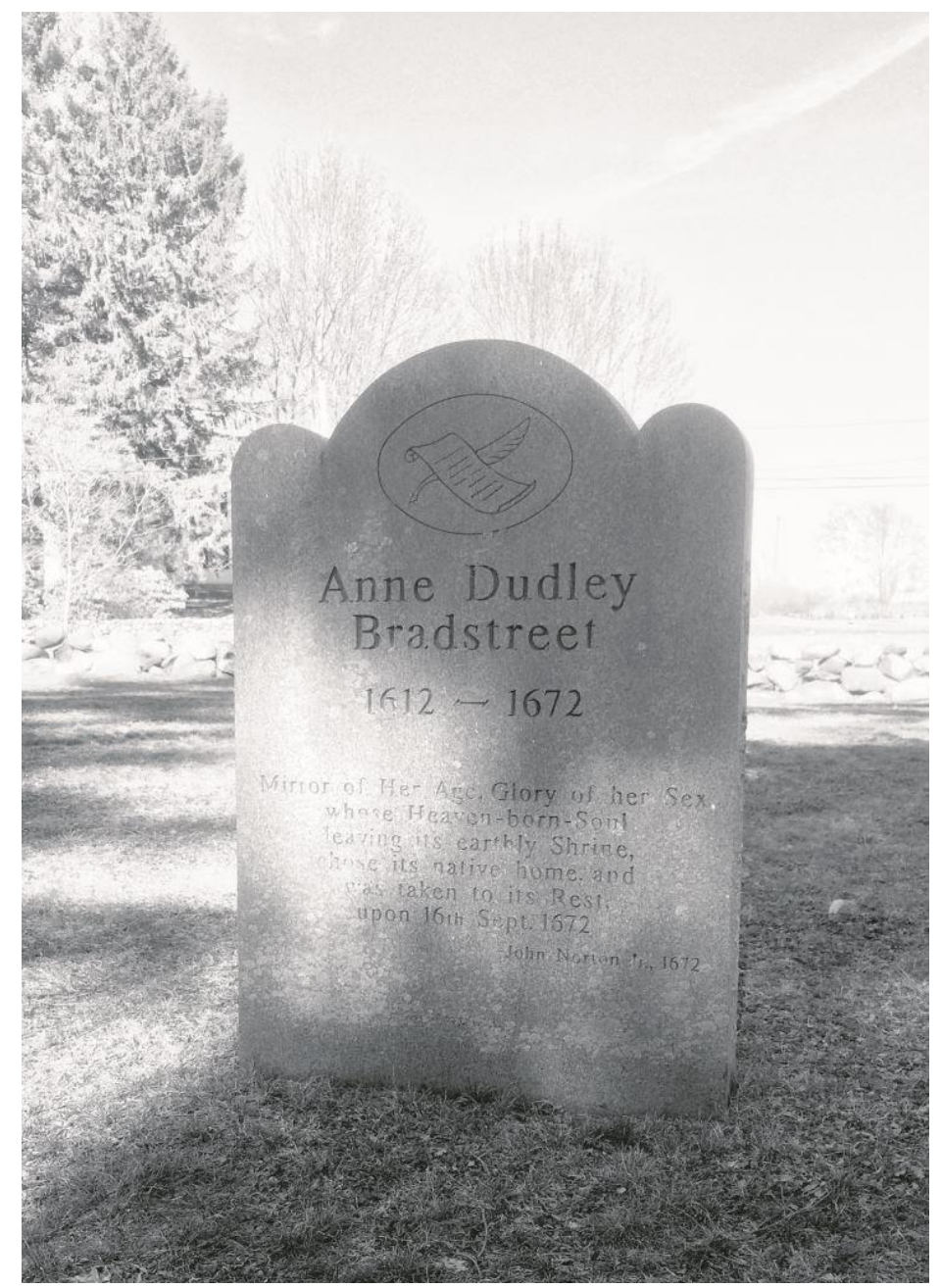

Figure 8: Monument for Anne Bradstreet, 2000. Old Burying Ground, North Andover, MA. Photograph by Iman Khadija Berrahou. By permission of the North Andover Historical Commission, North Andover, MA, USA.

these works by her children and posterity constructs her monument and continues the work of her family. ${ }^{71}$ Although John Ellis speculates that Bradstreet may have been buried with her father (not her parents) in Roxbury, an entry in the parish records of Andover notes, " $\mathrm{M}^{\mathrm{rs}} \mathrm{An}$ Bradstreet, wyfe of $\mathrm{M}^{\mathrm{r}}$ Simon Bradstreet, dyed 16 September and was buried the Wednesday

\footnotetext{
${ }^{71}$ Bradstreet's great-grandson, Rev. Simon Bradstreet of Marblehead, translated the dedicatory epistle and first four "Meditations" into Latin (AM 69-72). A copy of the manuscript, Harvard AM MS 1007, is extant, written in the hand of Sarah Bradstreet, probably Bradstreet's daughter (d. 1690) but possibly her granddaughter (d. 1762).
} 
after 1672."72 On the 350th anniversary of the publication of The Tenth Muse, the North Andover Historical Commission erected a monument to Anne Bradstreet in the Old Burying Ground that lies near the site of her fleeting home (see figure 8). ${ }^{73}$ Although burial in an unmarked grave reflected the modesty of Bradstreet's Puritanism more than that of her sex, twentieth-century admirers found her specifically female corpse worthy of celebration. ${ }^{74}$ The epitaph engraved on her monument is not of her authorship, but recovers a verse from John Norton's elegy for Bradstreet, published in Several Poems (252):

$$
\begin{aligned}
& \text { Mirror of her Age, Glory of her Sex, } \\
& \text { whose Heaven-born-Soul } \\
& \text { leaving its earthly Shrine, } \\
& \text { chose its native home, and } \\
& \text { was taken to its Rest, } \\
& \text { upon } 16^{\text {th }} \text { Sept. } 1672 \text {. }
\end{aligned}
$$

It is easy to imagine that no suitably ethereal emblem presented itself in Bradstreet's own resistant, revisionary corpus, committed as it is so thoroughly to matter. Against the epitaph's disembodied, transcendental metaphors - a "bodiless flight," to borrow Stacy Alaimo’s phrase-Simon Bradstreet's "Memoires" provides an epitaphic figure more characteristic of

\footnotetext{
${ }^{72}$ Ellis, ed., Works, lvx; and Andover Town Hall, MS 1.10, R. 23, "Town of Andover, A Record of Births (1651-1700), Deaths (1650-1700), and Marriages (1657-1700)," fol. 42 . September 16, 1672 was a Monday (Julian calendar).

${ }^{73}$ The Parson Barnard house which stands near the burying ground in North Andover was long thought to be Anne Bradstreet's rebuilt home, but it was erected in 1715 on a pasture purchased from Bradstreet's son Dudley. Bradstreet's second home may have been adjacent, on the current site of the Philip Manse house. I am indebted to Inga Larson, North Andover archivist, for this information.

${ }^{74}$ See David Stannard, The Puritan Way of Death: A Study of Religion, Culture and Social Change (Oxford University Press, 1977), 116-17; and see Rev. Simon Bradstreet's "Memoires," New England Historical and Genealogical Register, 9 (1855), 45, which report that when " $\mathrm{M}^{\mathrm{r}}$ Francis Willougby, Deputy Gover of the Massachusetts Colony, dyed" in April 1671, "He desired to be buried ten foot deep and to haue $\mathrm{y}^{\mathrm{e}}$ top of his grave plaine, only couered $\mathrm{w}^{\text {th }}$ the turfes of $\mathrm{y}^{\mathrm{e}}$ grasse."
} 
his mother. 75 "My ever honoured \& most dear Mother was translated to Heaven," he writes, regretting having been absent at her deathbed and thus losing "the opportunity of comitting to memory her pious \& memorable expressions vttered in her sicknesse." ${ }^{\text {,6 }}$ But he had, of course, encouraged his mother to commit her legacy to paper, which he himself copied after her death. ${ }^{77}$ The manner of his mother's death resonates with her book of the body:

Her death was occasioned by a consumption being wasted to skin $\&$ bone $\&$ She had an issue made in her arm bee[cause] she was much troubled with rheum, \& one of $\mathrm{y}^{\mathrm{e}}$ women $\mathrm{y}^{\mathrm{t}}$ tended herr dressing her arm, said shee never saw such an arm in her Life, I, said my most dear Mother, but $\mathrm{y}^{\mathrm{t}}$ arm shall bee a Glorious Arm. ${ }^{78}$

Bradstreet's arm is at once translated to heaven and inextricably, excruciatingly laced to the earthly frame; a fragile, fleshy, glorious emblem of Bradstreet's entanglement in a world in whose threshold she waits.

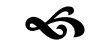

The global aim of this article has been to demonstrate the advantages of a new materialist approach to early modern women's writing. Locally, I also attempt to respond to the bifurcated critical reception of Bradstreet's works. The early, essentialist appreciation of Bradstreet's posthumous poems as private and autobiographical, far superior to those of The Tenth Muse, has been overtaken by the critical recovery of Bradstreet as a public and political

75 Alaimo, Undomesticated Ground, 10.

${ }^{76}$ Quoted in Ellis, ed., Works, lxiv-lxv.

${ }^{77}$ Bradstreet notes the weight given to deathbed speeches as her reason for writing: "I knowing by expair. $\mathrm{y}^{\mathrm{t}} \mathrm{y}^{\mathrm{e}}$ exhortat. of parents... sink deepest $\mathrm{w}^{\mathrm{ch}}$ are spoke latest, \& being ignorant whether on my death bed I shall haue opportunity to speak to any of you, much lesse to all" (AM 43).

${ }^{78}$ Quoted in Ellis, ed., Works, lxiv-lxv. 
poet. ${ }^{79}$ As attention has moved away from Bradstreet's manuscript poems toward those she printed, the "Andover Manuscript" has generally been overlooked—perhaps seen as effusively 'feminine' or fanatically 'religious. ${ }^{80}$ I have argued here that it is not the medium of Bradstreet's writings — manuscript or print — that determines her relative publicity or privacy, conformity or challenge. Rather, I encourage a shift in focus to consider materiality, not only of the book but more broadly of its author and environment, arguing that a reading which "operat[es] through a kind of grounded immersion rather than bodiless flight" can unite these polarized views. ${ }^{81}$ Taking into account Bradstreet's reluctance to leave behind the natural, artifactual, and cultural spaces where her life played out, or the tokens of their passing, may help to mend the fissure dividing this critical field. ${ }^{82}$

\footnotetext{
${ }^{79}$ For the earlier view, see Adrienne Rich, "Anne Bradstreet and her Poetry," in Hensley, ed., Works, x-xxii. For political readings, see Wright, Producing Women's Writing, 57-96; Gillespie, Women Writing, 194-241; Mihoko Suzuki, "What's Political in SeventeenthCentury Women's Political Writing?" Literature Compass, 6.4 (2009), 927-41; and Gillespie, "'This briny ocean."”

${ }^{80}$ For a notable exception, see Lutes, "Negotiating Theology.

${ }^{81}$ Alaimo, Undomesticated Ground, 10.

${ }^{82}$ I wish to thank the members of the Race/Gender Matters Research Group at Kingston University London for their insightful and collegial comments on an early draft of this essay.
} 